Superimposition: How Indian city bureaucracies are responding to climate change

Ankit Bhardwaj ${ }_{1}{ }^{*}$, Radhika Khosla2

Author affiliations

${ }_{1}$ Department of Sociology, New York University, New York, United States of America

2 Smith School of Enterprise and the Environment, School of Geography and the Environment, University of Oxford, Oxford, United Kingdom

${ }^{*}$ Corresponding Author:

Email: ab3629@nyu.edu

\title{
Acknowledgements
}

We thank the Swiss Agency for Development and Cooperation and the MacArthur Foundation for their support of this project conducted at the Centre for Policy Research, New Delhi. We also thank Colin Jerolmack, Alex Barnard, Claire Sieffert, Aditya Valiathan Pillai, Parth Bhatia, and the participants at the talk at Centre d'études en sciences sociales sur les mondes africains, américains et asiatiques, Paris, who provided generous comments on drafts of this article. The responsibility of all errors rests with the authors.

This manuscript has been accepted for publication and is forthcoming in Environment and Planning E: Nature and Space. 


\section{Superimposition: How Indian city bureaucracies are responding to climate change}

\section{Abstract}

City governments are facing the complex challenge of climate change, but those in the global South often have limited capacities and governance arrangements to develop and execute a response. Cities must also manage other existing priorities such as housing, water, and waste management, which have established bureaucratic practices and incentives. How are such cities with limited climate governance capacity and with existing non-climate priorities developing a climate response? From interviews and participant observation in two Indian cities that are pioneering climate action, we find that actors are "superimposing" climate objectives onto existing bureaucratic practices. Building on analysis of ongoing projects in the two cities, we theorize superimposition as an approach taken by bureaucracies that have the intention of responding to climate change but have limited control over their planning practices and mandates, high levels of institutional inertia to change existing practices, and multiple other objectives related to development that dominate agendas. As superimposition does not involve the modification of existing bureaucratic practices or incentives, the types of actions which emerge from this approach to responding to climate change reflects the scope and limitations of existing political arrangements and features. We highlight five such features of how Indian city bureaucracies respond to climate change: 1) the primacy of central and state 'schemes'; 2) the prioritization of 'development' as an objective; and the imperative to implement 3) 'quick win'; 4) 'visible'; and 5) 'bankable' projects. Superimposition has led to creative and politically-tenable climate projects that meet both climate objectives and those of existing schemes on housing, water, and waste. But these projects are also limited by existing governance arrangements with trade-offs for long-term planning, urban justice, and public ownership of infrastructure.

Keywords: climate change, urban governance, local climate action, global South, India 


\section{Introduction}

City governments in the global South are facing the complex challenge of simultaneously managing rapid urban transformations in their jurisdictions; providing access to basic infrastructure services, such as modern energy, clean water, sanitation, and shelter; and restoring degraded local environments. Climate change adds an additional degree of complexity to this challenge by stressing already stretched infrastructures, environments, and social structures. Cities in the Global South are projected to be the most vulnerable to climate change (Nagendra et al., 2018). Climate change will also bring the additional imperative for cities to reduce new infrastructure's ecological footprint and greenhouse gas (GHG) emissions (Lele et al., 2018). Indeed, the development of urban infrastructure in the global South will have deep implications for global GHG mitigation, requiring an estimated 226 Gt of carbon dioxide (Bai et al., 2018). How city governments are responding to this complex set of challenges is determined by the cities' existing political arrangements. On the face of it, developing country cities with traditional bureaucracies have limited capacity to manage novel, complex problems, which does not bode well for their future health and ecology. Given these circumstances of urgent and varied urban objectives, heightened climate vulnerabilities, growing carbon emissions, and limited governance arrangements, how are urban responses to climate change being developed? What are the priorities of the responses, and what are they missing out?

This paper examines two second-tier, rapidly-growing cities in India that are beginning to address climate objectives in their governance. As early adopters of climate objectives, these cities are outlier cases that illustrate how city officials in India are integrating climate objectives into their decision-making. As medium-sized cities, both Rajkot and Coimbatore are also typical of those that host the majority of the Indian urban population (Birkmann et al., 2016; Denis and Zérah, 2017), and therefore also do not have dedicated institutions to devise and execute a response to climate change. Motivated by our position as academics located in the global South 
during the course of research, we portray the cases of these two medium-sized cities in the global South with an eye towards correcting the bias towards mega- and global North cities in the literature on urban climate action (Lamb et al., 2019) and theorizing how urban climate responses are fashioned in different global regions (Robinson and Roy, 2016; Roy, 2009). Methodologically, this study is based on empirical, semi-structured interviews and discussions with actors in the cities of Rajkot and Coimbatore in India over two years (2016-2018). Our engagement in these cities over the two-year period involved numerous and repeated interactions with actors within the city, state and national government, non-governmental organizations, the private sector, community representatives, and with international organizations and funders. This was complemented by participant observation and interaction with these various actors in meetings on climate change and urban governance in the cities, and document analysis of city plans and schemes.

While there has been emphasis in the urban climate action literature on the development of novel institutions and planning frameworks to respond to climate change, we argue that the governments of these rapidly growing Indian cities are already using their existing bureaucratic practices to respond to climate change. The two cities are, as one city leader put it, 'superimposing' climate objectives onto existing development schemes and bureaucratic practices. Specifically, we identify five bureaucratic practices that characterize the type of climate action pursued: 1) the primacy of central and state 'schemes'; 2) the prioritization of 'development' as an objective; and the imperative to implement 3) 'quick win', 4) 'visible', and 5) 'bankable' projects. Our study reveals the complexities of climate governance in Southern cities, where addressing climate change is but one of city's multiple objectives and where the primary incentives are to develop infrastructure. We also find that local political arrangements and capacities, rather than global imperatives to respond to climate change or the influence of nonstate actors, determine the course of urban climate action, as well as cities' abilities to 
experiment, integrate across sectors, engage multiple actors, and address multiple objectives -what we term the normative goals of climate action planning. We argue for further emphasis on the agency of Southern cities and exploring how their different capacities and arrangements influence climate responses.

We begin with discussing the existing literature on city climate action. We then explore the features that characterize the politics of Indian urban governance, and in particular the cities of Rajkot and Coimbatore and their institutional arrangements and priorities. In the subsequent sections, we develop our findings on how these institutional arrangements and priorities influence and determine climate responses.

\section{Urban governance of climate change: the politics of addressing complex problems}

In both academic and policy discussions, city governments are boosted as strategic institutions in the global response to climate change (Bouteligier, 2012; Castán Broto, 2017; Gordon, 2018; Rosenzweig et al., 2010; Solecki et al., 2018). In this flattering light, city governments are seen as innovative, experimental, and having the political and technical acumen to deploy low-carbon and resilient infrastructure (Acuto, 2013; Bai et al., 2018; Barber, 2013; Bouteligier, 2012; Boyd and Ghosh, 2013; Castán Broto and Bulkeley, 2013; Johnson et al., 2017; Sallis et al., 2015). The potential and perceived operational ease of climate action in cities has resulted in numerous state and non-state actors, as agents of policy mobility, to hone in on cities as sites of climate action (Betsill and Bulkeley, 2004; Fisher, 2014; Fünfgeld, 2015; Goh, 2019; Lee, 2012). Effectively, these actors are becoming 'city-ists', placing primacy on the city-level to respond to global ecological and social problems (Angelo and Wachsmuth, 2015; Wachsmuth, 2014). This is part of an ongoing paradigm shift towards "climate urbanism" where urban policies, programs, and initiatives are increasingly aimed at addressing climate mitigation and adaptation objectives (Long and Rice, 2019), creating new rationalities and configurations of climate governance (Castán Broto, 2017). 
One reason offered for this shift towards cities as strategic climate actors is the concentration of economic, demographic, and social change in urban areas, which creates the conditions and necessity to respond to climate change (Acuto et al., 2018; Gordon, 2018). Another reason is the potential for cities to govern with a systems, multi-sectoral, multi-actor, or 'combinatorial' approach (Acuto and Parnell, 2016; Amin and Thrift, 2016; Bai et al., 2016). Such approaches are touted as suitable to address complex, wicked problems such as climate change, i.e. problems that are hard to define, are uncertain and ever-changing, and are complex in terms of their interconnections with social, political, and environmental systems (Frame, 2008; Head and Alford, 2015; Hulme, 2009, 2010; Rittel and Webber, 1973). In the spirit of addressing wickedlike problems, many normative planning frameworks and policy recommendations aim to assist city decision-makers to engage multiple actors, integrate across multiple sectors, and address multiple objectives (Andrews et al., 2017; Bai et al., 2016; Basu et al., 2019; Bhardwaj et al., 2019; Frame, 2008; Freeman and Yearworth, 2017; Head and Alford, 2015; Jabareen, 2013). City climate responses are also already being crafted in this vein. A recent review of urban climate action identified that cities as sites of experimentation in climate action, co-ordination with multiple actors and stakeholders, and integration with larger multi-level and multi-sectoral governance structures (Gordon, 2018).

But often cities' ability to experiment, engage with multiple actors, integrate across sectoral divides, and address multiple objectives (i.e. the goals of the normative planning and policy literature) is a function of the political arrangements and power relations governing the city. Emphasis on the political and contested nature of urban climate governance is characteristic of the recent 'second wave' of urban climate literature (Braun, 2014; Castán Broto, 2017; Gordon, 2018; Hughes, 2017; Luque-Ayala et al., 2018; Romero-Lankao et al., 2018). Political and governance arrangements have inertias and path dependencies due to the prevalence of existing bureaucratic practices, vested interests, and dominating coalitions (Knox-Hayes, 2015; 
Knox-Hayes and Hayes, 2014; Seto et al., 2016). City governments can often find it hard to wrestle away from existing arrangements and adopt new planning and bureaucratic processes aimed at addressing new issues like climate change (Aylett, 2013), even when provided "external" incentives from transnational actors or the global climate regime (Anguelovski and Carmin, 2011; Bellinson and Chu, 2019; Chu, 2018; Gordon, 2018). This has led scholars to investigate the "internal", "innate", "endogenous", or local political dynamics and configurations of cities, and how they determine climate action (Aylett, 2013; Bellinson and Chu, 2019; Hodson et al., 2017; McGuirk et al., 2016; Ryan, 2015; van der Heijden et al., 2019), alongside other scholarship aimed at understanding the role of domestic and endogenous institutions in managing global environmental and climate change (Andonova et al., 2017; Fragkias and Boone, 2016). Such scholarship has emphasized the administrative, legal, policy, financial, and bureaucratic practices that are "entrenched" in cities, and remain influential in determining actions even when addressing novel objectives such as climate mitigation and adaptation (Anguelovski and Carmin, 2011; Chu, 2018; Ryan, 2015). The features and characteristics of city climate responses are largely determined by the specific political economy, socio-material, and institutional contexts that the cities are already embedded in, as opposed to the establishment of new governance arrangements to respond to climate change (Broto, 2017; Rutherford and Coutard, 2014). An implication of such work is that there is nothing implicit in 'cities' that make them rarefied actors in the global climate response (Wachsmuth, 2014), and indeed they can even be barriers to effective climate action (Fisher and Leifeld, 2019).

An equally important and related insight is that endogenous objectives, concerns, and priorities — even if unrelated to or silent on climate change - motivate urban climate action (Anguelovski and Carmin, 2011; Aylett, 2014; Castán Broto, 2017; Khosla and Bhardwaj, 2018; Koslov, 2019; Kousky and Schneider, 2003; Slocum, 2004). Such 'co-benefits' have been identified as crucial in motivating climate action as they bring with them immediate benefits, such as development or 
welfare, which local actors are familiar with and directly benefit from. In addition, local actors are more likely to have entrenched incentives to address these "co-benefits" to climate action, therefore leading to the sustained occurrence of actors "bundling" local concerns and immediate priorities with climate mitigation and adaptation objectives (Aggarwal, 2013; Cook and Chu, 2018; Harrison and Kostka, 2018; Koehn, 2008). This bundling is of particular relevance to decision-makers in the global South who are seeking to find ways to respond to climate change, but whose development and welfare concerns can overwhelm explicit climate objectives (Bhardwaj et al., 2019). As case studies of climate action have shown, identifying 'win-wins' between development and climate change can motivate responses (Fisher, 2012; Khosla and Bhardwaj, 2018). However, actions to simultaneously address climate and existing objectives, with entrenched practices, need not always be win-win, and can create perverse incentives, or reinforce unjust planning, development, and decision-making practices (Chu, 2018; Harrison and Kostka, 2018).

Critical scholars have identified the influence of entrenched neoliberal, entrepreneurial, and monetizing practices of Global North cities on the types of climate actions pursued (Acuto, 2012; Eadson, 2012; Jonas and While, 2007; Long and Rice, 2019; Rice et al., 2019; While and Whitehead, 2013). Armed with high technical capacities, these cities have created new institutions and governance logics with metrics to manage carbon and climate risk, often with the ability to 'bypass' national political systems that inhibit climate action (Aylett, 2013; LuqueAyala et al., 2018). Such a 'carbon calculus' and 'carbonization' of urban governance is dataintensive, requiring access, collection, and processing of carbon accounts, as well as legibility over multiple sectors within city territories (Eadson, 2012; Jones, 2018, 2019; Long and Rice, 2019; Rice, 2010; Rutland and Aylett, 2008). Examples from Seattle and Portland show how the cities developed new institutions, new forms of data, and new practices of governance to cope with climate change (Rice, 2010; Rutland and Aylett, 2008). These approaches are critiqued as 
'neoliberal' climate actions as they prioritise monetization above other values (Knox-Hayes, 2015), and pursue profit and agglomeration of local capital over social interests (Jonas and While, 2007; While and Whitehead, 2013).

While a few studies have emphasized the neoliberal practices of urban climate action in the Global South (Anguelovski et al., 2019; Silver, 2017), many documented experiences are decidedly different from those of the North. This is because many cities in the South do not have the capacity, data, nor political capital to create new systems of climate and carbon governance and have overwhelming priorities to meet development objectives. Only a few developing country cities, for example Surat and Durban, have found the political and financial capital to create new institutions governing climate change (Aylett, 2010; Carmin et al., 2012; Chu, 2016; Roberts, 2008). Even so, Southern cities follow various pathways of climate action that are contingent upon their existing governance capabilities and capacities. A comparative study across Durban, Quito, and Surat uncovered a diversity of approaches dependent on who the core driver of the process was and whether local government was organized to have a strong independent climate department or mandated participation (Anguelovski et al., 2014).

While many have emphasized the role of non-state and transnational actors in motivating climate action in Global South cities (Fisher, 2012, 2014; Fisher et al., 2018; Fünfgeld, 2015; Goh, 2019; Gordon, 2016; Khosla and Bhardwaj, 2018; Silver, 2017), the role of a city government's own agency remains critical (Borie et al., 2019; Chu, 2018; Heinrichs et al., 2013). Studies focused on the involvement of influential trans-national and non-state actors in global South cities have emphasized that climate action involves bypassing existing political practices and forming experimental, hybrid arrangements. For example, in Mumbai, strong civil society or para-statal agencies led action (Boyd and Ghosh, 2013); in Surat, the Rockefeller Foundation led the creation of an independent Surat Climate Change Trust (Chu, 2016; Karanth and Archer, 2014); in Bangalore, a private developer constructed climate-friendly housing (Bulkeley and 
Castán Broto, 2014); in Mbale, the World Bank funded and dominated the agenda of climate mitigation projects (Silver, 2017); in Jakarta, Dutch expertise co-developed a plan with the government to make Jakarta flood resilient (Goh, 2019). But, as we note above, local political economy, extant domestic institutions, existing bureaucratic incentives, and local actors are also significant determinants of the objectives of climate action, even in collaboration with transnational and non-state actors. In the case of Surat, in spite of the presence of a large external actor, local municipal governance and political economy influenced the priorities of the city's climate action (Blok, 2016; Chu, 2016). Local political arrangements determine how Global South city governments incorporate climate science or structure relationships with non-state actors (Anguelovski et al., 2014; Borie et al., 2019; Fisher et al., 2018; Hughes and RomeroLankao, 2014). Cities have independent and domestic agencies, even in the face of influential and domineering non-state and trans-national actors (Chu, 2018).

This 'bureaucratization' of climate action at the city-level (Chu, 2018) tunes our attention to how particular bureaucratic practices influence the formulation, implementation, and management of climate action. First, is the role of 'everyday governance' and how bureaucratic actors operate given visible official rules, social norms, and unwritten codes of conducts and values noting the gap, or 'loose coupling', between official pronouncements and actual bureaucratic practice (Cornea et al., 2017; Leck and Roberts, 2015; Meyer and Rowan, 1977; Patterson and Huitema, 2019). Second, scholars of institutional change have noted that actors have embedded practices and interests, which lead to an inertia, or 'path dependency' in the adoption of new objectives, such as reducing carbon emissions or adapting to climate risks (Kameo, 2015; KnoxHayes and Hayes, 2014; Meyer and Rowan, 1977). New objectives can be adopted, but are often modified, to be suited to, and legitimate for local, existing interests (Weber, 1921). Finally, there are tradeoffs to bureaucratic approaches to address complex, risk-laden problems. Scholars concerned with addressing wicked problems have criticized conventional bureaucratic 
techniques of siloing problems, delivering atomized tasks, and performing in response to incentives from higher rungs of the bureaucracy as only being able to deal with 'tame' problems such as delivering units of housing (Rittel and Webber, 1973). Bureaucracies have a tendency to manage and cope with the symbols or "cosmetics of risk", rather than the sources of the risks themselves (Beck, 1992: 57). Bureaucrats can emphasize actions that are visible, and symbolically important, rather than processes and practices that could prevent risks, or address them systematically (Ghertner, 2015; Scott, 1999). What then, in our cases, are the practices that characterize the agency of Indian city bureaucracies, and how do they influence the types of climate action pursued? What tradeoffs are there with the bureaucratic approach? We address these through the case study of Rajkot and Coimbatore.

\section{Rajkot and Coimbatore: Indian city bureaucracies as climate actors}

Part of the motivation to select these two cities as sites to investigate climate change governance is their relative engagement with climate action in comparison to most Indian cities

(Bhardwaj and Khosla, 2017, 2018). Our approach was to identify city governments in India that proactively began addressing climate considerations and investigate how they were doing so. The city of Rajkot has emerged as a national climate change champion, being the only Indian city to be part of the Global Covenant of Mayors, and it won the WWF 'National Earth Capital' Award in 2016 and 2018 (WWF-India, 2018). Both cities have programs of work on climate change, with support from international organizations such as the World Bank and ICLEI-South Asia and development assistance from the US, Germany, and Switzerland, among others (Bhardwaj and Khosla, 2017, 2018). With track records of climate action, these cities are two standout, illustrative cases that give an indication of how other city governments in small to medium cities in India can address climate change within existing governance arrangements. 


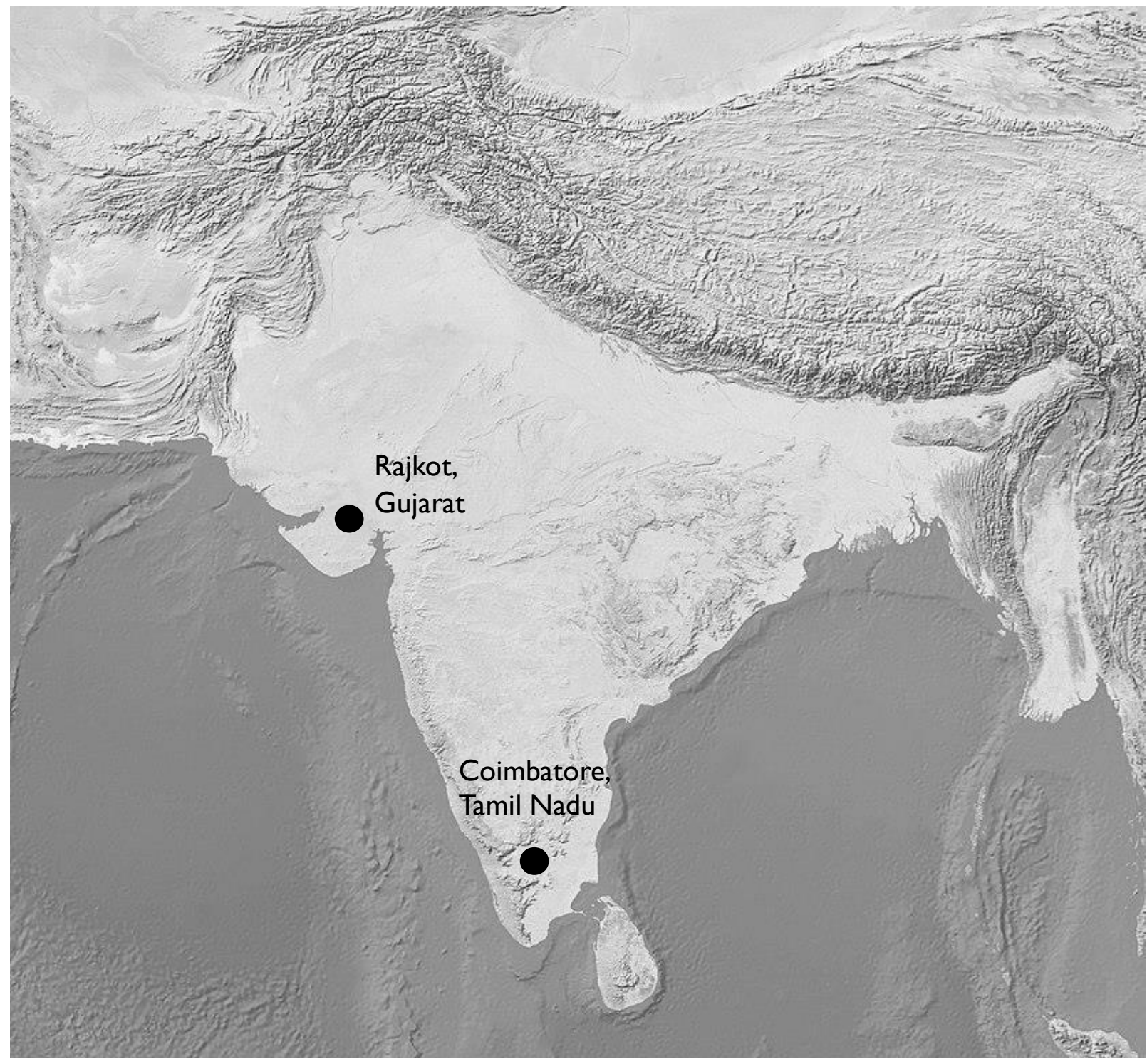

Figure 1 Location of Rajkot, Gujarat and Coimbatore, Tamil Nadu in India.

Methodologically, we ascertained details of local climate action through semi-structured, inperson interviews, document analysis, and participant observations at project sites and meetings. We interviewed city-level actors including bureaucrats, elected representatives, engineers, and members of local non-governmental, environmental, community and business organizations. We also interviewed state-level bureaucrats with relevant portfolios such as urban development and climate change. Interviews focused on details of previous and ongoing projects relating to climate change in the two cities, including how projects were conceived, 
financed, and implemented. Interviews were corroborated with analysis of documents such as the city's masterplans, schemes, and project reports, which included further details on finances, technical features, and governance. While conducting and coding interviews and analyzing documents, attention was given to the actor's multiple objectives for the project. Finally, further evidence was collected through participant observations at the sites of existing and proposed projects, and of meetings and workshops on climate change in the city. The meetings and workshops were forums where city leadership and officials from relevant departments, external funding organizations, and relevant stakeholders from civil society and local businesses, deliberated local infrastructure and climate action. Participant observation enabled interactions with individuals critical of local climate action. In-person interviews and observations were conducted between 2016 and 2018, when both researchers were based in New Delhi, and involved in a research project on urban climate action in support of city efforts. Multiple visits to the two cities positioned the researchers to gain a familiarity with local actors, allowing numerous and repeated interviews and meetings, and observation of how projects developed over time.

In interviews, local actors from both cities shared plenty of motivations to respond to climate change ranging from the visibility of climate change on the global stage, and the prestige and promotions climate actions could bring; acting altruistically, or prudently in the face of climate risks; being incentivized by bureaucratic leadership to address climate change; and to access additional financial and technical resources from non-state actors. Motivations influenced the types of actions pursued, especially those linked with bureaucratic incentives, but the diversity of motivations that individual, local actors shared in addressing climate change also indicated that no single motivation was crucial in generating local climate action. Some interviewees even expressed skepticism of climate change and climate action, stating that risks were overplayed, development was more important, and that they had faced more risk in the past, yet they 
worked on climate relevant projects. As a single and overarching motivation for climate action was not a necessary condition for climate action, we emphasize the mechanisms by which bureaucratic actors, with a diversity of motivations and interests, come to respond to climate change. Further, our focus on what actors do can be verified by their self-reported accounts during interviews with through participant observation and document analysis (Jerolmack and Khan, 2014; Weiss, 1995).

Rajkot and Coimbatore are among a number of emerging second-tier cities in India where the largest levels of urbanization and growth are predicted to occur (Bhardwaj and Khosla, 2017, 2018; Government of India, 2011). The cities are rapidly growing in population, driven by increasing economic growth, and they each face multiple, interconnected concerns. Urban sprawl is linked with a decreasing green cover, which is extremely low in Rajkot at 4\% (RUDA, 2015), and Coimbatore's sprawl is pushing development into biodiversity zones, increasing animal-human conflict and decreasing forest cover (Rajashekariah, 2011). Increasing sprawl is also linked with implications for water provision. In Rajkot, which is a very dry and water-poor city, lack of universal water access has led to the dissemination of borewells which are depleting ground water supply. Residents of Rajkot receive water for a mere 10-20 minutes a day, which is at further risk with increasing extreme weather events. During the course of this study itself, Rajkot suffered flooding due to higher than average rain (Skymet, 2017). Coimbatore, by contrast, is relatively water rich. Coimbatore's water is primarily supplied by dams in the Western Ghats, a mountain range that receives a monsoonal recharge, and is managed by the state's water board. The municipal corporation also has multiple lakes within its jurisdiction, though many are in a degraded state and do not hold water reserves. Studies, however, suggest that Coimbatore is at risk with increasing climate change (Dholakia et al., 2015; ICLEI South Asia, 2017c). Both these cities face many urgent, complex, and interconnected 
challenges in their delivery of urban services for development, and yet are also sites where long-term concerns, such as those posed by climate change, are slowly taking root.

One of our additional goals was to understand how cities with no specialized climate institution or heightened governance capacities can respond to climate change. Both cities are headed by Municipal Commissioners, who are State-appointed members of the national bureaucratic cadre: the Indian Administrative Services (IAS). IAS officers occupy high ranking positions across the Indian bureaucracy and have strong incentives for promotion to national bureaucratic offices. The Municipal Commissioner post usually has a term of three years, with the priority of undertaking tasks directed by the state and centre (Ahluwalia, 2017; Andrews et al., 2017), and therefore operate with short-term preferences in mind. As a result these cities, with limited political and financial capital to create new institutions governing climate change, use existing schemes and agendas aimed at development as the starting point for climate action and associated political contestations (Carmin et al., 2012; Khosla and Bhardwaj, 2018). Crucially these schemes need not be explicitly related to climate change but can instead be about addressing welfare and infrastructure development objectives such as sanitation, transportation, housing, and healthcare. This understanding of scheme-based operations is also reflected in the changing ambition of non-state actors influencing Indian urban governance, who have shifted from a focus on the development of spatial masterplans in the 1950s onwards (Engerman, 2018; Sundaram, 2010) to the implementation of discrete projects that can achieve tangible and measurable impact, as well as better reflect bureaucratic norms (Khosla et al., 2017; Klingebiel et al., 2016; Muller, 2019).

Along with IAS officers, both cities also have elected Mayors, but their offices have no formal decision-making or executive powers (Ahluwalia, 2017; Sivaramakrishnan, 2013). Urban governance in India is relatively centralized, (Ahluwalia, 2017; Khan et al., 2018; Nandi and Gamkhar, 2013; Sivaramakrishnan, 2013), and city governments can be understood as 
branches of state or central governments. City officials feel more responsible to the Chief Minister of the State or higher levels of bureaucracies than to local representatives (Krishnankutty, 2018), expressed by the dominance of bureaucratic motivations to respond to climate change amongst actors interviewed. The influence of government's central, state, and regional levels on urban climate governance is a well-documented process in the multi-level governance literature, including in India (Betsill and Bulkeley, 2006; Bulkeley and Betsill, 2003; Jörgensen et al., 2015; Sami, 2017). In China, another centralized governance system, scholars note the 'shadow of hierarchy' that governs provincial governments' urban climate experimentation (Miao and Li, 2017). Upper levels of the hierarchy can use mechanisms of coercion (top-down), competition, and collaboration (deliberation, negotiation, and compromise) that can work towards creating sub-national climate action (Gordon, 2015).

Another feature of Rajkot and Coimbatore is that the cities are institutionally relatively simple with limited fragmentation, unlike mega-cities in the global South. Most urban services are governed by the "Municipal Corporation," with limited capacity to co-ordinate across sectors or devise and execute plans. City departments in city governments are in charge of implementing handed-down directives and schemes from individual line ministries. Inter-sectoral, spatial urban plans have little influence over urban growth and decision-making (Krishnankutty, 2018) and planning authorities have little ability to enforce planning standards (Ahluwalia, 2017; Gandhi and Pethe, 2017; Gururani, 2013; Kundu, 2014; Sivaramakrishnan, 2013). Both Rajkot's and Coimbatore's Commissioners decried that their "city is not planned", making their job more difficult.

A crucial reason as to why 'Indian cities cannot plan' are the pervasive informalities that condition how city bureaucracies operate (Gururani, 2013; Roy, 2009b). Often with low capacity, bureaucracies cannot enforce norms, and local political actors operate informally and in the gaps between official norms and standards. For example, Shubra Gururani (2013) notes how 
such informal arrangements form an ethic of 'flexible planning' where existing masterplans and planning conventions can be flouted at the influence of powerful local actors. At the same time, urban bureaucrats also have a degree of creative flexibility with official state and central directives that they can use to garner some agency and independence to address domestic objectives. This was seen in Surat, where local actors used a partnership with transnational actors to enable climate action across multiple sectors, bypassing the need for state approval. This has also been documented in other cases in the global South, for example in the eThekwini Municipality in South Africa, where the 'invisible aspects' of municipal institutions, including informal and shadow aspects such as personal relationships and soft norms and values, can influence the course of climate action (Leck and Roberts, 2015).

Financially, Indian cities have limited ability to generate new revenue, apart from user charges on urban services. Under the new Goods and Services Tax regime, introduced in 2017, city governments are unable to generate revenues through taxes. Instead, most Indian cities, including those in question, are dependent on schemes and programs devised by states and central governments for revenue. These are primarily schemes aimed at development and infrastructure welfare outcomes such as the construction of toilets and housing, the deployment of buses for public transit, and the extension of piped water supply, sewage treatment and waste management networks, and they have financial outlays linked to scheme achievement and performance of implementation. As a result, Indian cities are incentivized to remain fiscally responsible and not run over scheme budgets, but are also often in search of additional funds to pursue additional projects (Kundu, 2014; Zérah, 2009). In contrast to the general understanding of neoliberal, entrepreneurial, and metric-based governance of climate action, in India, while revenue-based reforms have incentivized monetization of urban services, there is little active role for cities to play in the broader economy of the city as they have no control over economic policy. Effectively, Indian cities are engines of growth 'without drivers' (Mukhopadhyay, 2018), 
and apart from leveraging land assets, cities have few economic levers to pull. However, there exist deep vested interests and crony urban regimes in the delivery of urban services, which often influence the contracting of municipal service delivery (Heller et al., 2019). This political economy influences how and who delivers urban services.

It is against this backdrop of governance arrangements that Indian cities respond to climate change. The forms of climate action that can be pursued in Indian cities, and their possibilities and pitfalls, are limited by what bureaucracies can and cannot do. What are the characteristics of Indian city bureaucracies that determine the scope of their climate action? We offer a nonexhaustive list of five characteristics from India. The first is the emphasis on 'schemes' by Indian bureaucratic leadership. Second, these schemes are designed to achieve non-climate 'development' aims such as infrastructure development and welfare. Third, these schemes are linked to political cycles and have to be delivered in a time-bound manner, either political cycles or terms of office; city officials interviewed referred to this as finding "quick wins." Fourth, city officials often emphasize actions that are 'visible' to the bureaucratic hierarchy. Fifth, restricted financially, cities seek to make projects 'bankable' by gathering funds from schemes and other local and transnational sources. These five characteristics are specific to the Indian case where city governments operate in a bureaucracy incentivized to address centrally defined development, and with little local democracy, capacity, and independent financing. Like other global South cities, these characteristics reflect a lack of capacity to create new or reform institutional practices, such as data collection, monitoring, and management of carbon metrics. Indian cities also share some characteristics of cities in the global North, such as in the case of United States of America's cities dominated by short-term preferences and searching for new revenue streams, however, differ in crucial ways such as lack of democratic champions and capacity to track carbon emissions (Hughes, 2017; Rice, 2010). A study of superimposition 
points attention to how the specific practices of urban governance, regardless of whether they are in the global North or South, can influence the response to climate change.

How do the five identified characteristics of Indian city bureaucracies impact climate action and the ability for cities to experiment, engage multiple actors, integrate across sectors, and address multiple objectives i.e. respond to the wicked problem of climate change? What are the tradeoffs? The next section examines how the bureaucratic characteristics influence climate action in these two cities.

\section{Superimposition}

For the city bureaucrats we interviewed, responding to climate change was a secondary concern to the "more pressing" implementation of urban development schemes. These schemes rarely had climate change as an explicit consideration. As a result, both city governments had to find ways to address their climate considerations in light of their already existing, multiple, and non-climate priorities. Often these cities found ways to identify and converge their immediate city development priorities with climate change. As phrased by Coimbatore's municipal commissioner, to address climate change, they "superimposed the climate agenda" to ongoing urban schemes. Creating new urban institutions and practices to respond to climate change was out of the question as existing practices were far too entrenched and cities had little ability to modify them. Superimposition, in contrast, did not require altering existing urban development practices but rather introduced climate priorities to ongoing schemes that the city was already implementing. Therefore, while neither Coimbatore nor Rajkot (which followed a similar approach) set aside a climate change budget nor created a dedicated climate department; they superimposed climate change onto the multiple projects that these cities implemented under their existing schemes. 
As a concept, superimposition is a type of "mainstreaming", a term which conflates the incorporation of new objectives, actors, practices, and institutions into governance.

Mainstreaming can include the introduction of novel practices or institutions, such as climate planning and its normative goals, into governance. In superimposition, no new practices are introduced, and instead existing practices are aligned to achieve novel objectives, such as reducing carbon emissions or managing climate risks. Superimposition also differs from "integration" or "coordination" as it is not simply about bringing together actions that are splintered across departments and sector such as water, waste, and energy management. Superimposition could involve integration, but it could also simply be about making existing water practices more climate oriented. Differentiating superimposition from mainstreaming as a whole helps identify the levers of change that do not require the high amounts of technical capacity and political capital required to form new institutions or practices of climate governance, and therefore has practical and theoretical relevance for many cities with limited governance capacities in the global South.

Superimposition is the approach of responding to climate change by aligning climate objectives with existing bureaucratic practices and objectives, and includes identifying and acting upon cobenefits between climate and existing environmental, and social objectives (Bhardwaj et al., 2019; Doll and Puppim de Oliveira, 2017; von Stechow et al., 2015). The approach is one taken by bureaucracies that have the intention of responding to climate change but have limited control over their planning practices and mandates, high levels of institutional inertia to change existing practices, and multiple other objectives related to development that dominate agendas. Such bureaucracies govern Indian cities. Indeed, Coimbatore and Rajkot, like others, are led by bureaucrats who have little institutional mandate to undertake long-term strategic decisions or to raise independent funds, which conditions the types of climate projects they conceive of. As superimposition does not involve the modification of existing bureaucratic practices or 
incentives, the climate actions that emerge from this approach reflect the scope and limitations of existing bureaucratic practices.

The following section explores how the city bureaucracies superimposed climate change objectives onto the five bureaucratic practices identified in the section above (see Figure 2). Of interest is how the bureaucracies subsumed climate change concerns into their existing practices, and in doing so modified their actions and outcomes to address climate objectives.

Superimposition: or how Indian cities are responding to climate change
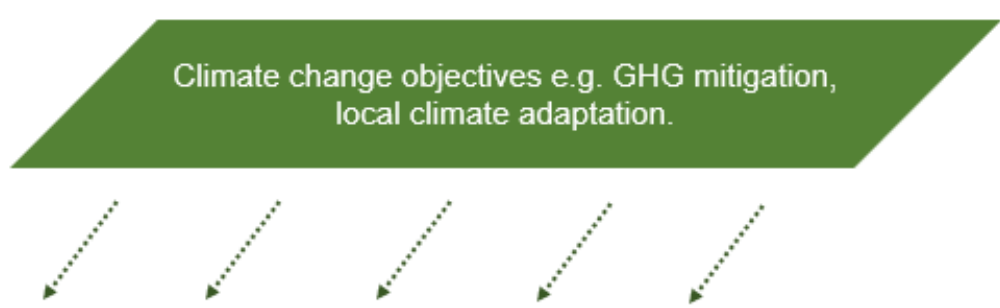

Existing bureaucratic practices and objectives

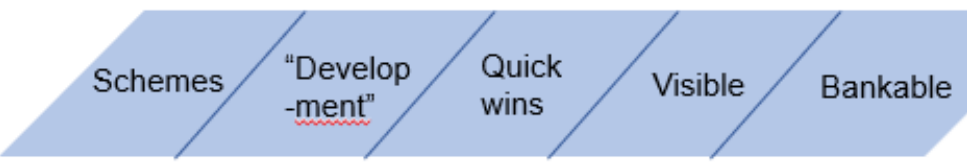

Figure 2: Superimposition of climate change objectives on bureaucratic practices and objectives of Indian cities

\section{Dominance of bureaucratic schemes}

As with ideal-type bureaucracies, the system of urban governance in India is designed with incentives to ensure that lower rungs of bureaucracy, appointed by state-level bureaucratic cadres, deliver tasks and targets set out in national and state schemes in a technocratic manner (Aylett, 2013; Weber, 1921). These incentives can come in the form of promotion along career paths, financial incentives, or social prestige, and influence the actions city leaders choose to undertake. For example, city bureaucrats were provided incentives to undertake action towards national flagship schemes, such as, India's Swachh Bharat Mission (which aimed at providing universal access to toilets and enhancing solid waste management systems), and the Pradhan 
Mantri Awas Yojana or 'Affordable Housing for All' program (which aimed to construct 12 million housing units between 2015 and 2022). Some schemes had explicit climate objectives, such as the Solar City Programme under the National Solar Mission (part of the National Action Plan on Climate Change), which aimed to deploy solar heater and photovoltaic technologies in cities. Tasked with the implementation of these schemes, bureaucrats were assessed on their ability to deliver units of toilets, units of solid waste processed, units of solar technology deployed, and units of housing delivered.

In municipal meetings, Commissioners in both cities often checked in with individual departments on their progress towards achieving goals of urban development schemes, often defined in unit terms such as kilometres of road built, or number of housing units developed. In a prior example, the implementation of the Jawaharlal Nehru National Urban Renewal Mission (JNNURM) was tracked based on delivery of centrally identified technical infrastructures such as units of flyovers, units of housing and units of buses.

Rajkot and Coimbatore pursued climate action within these parameters by devising climate projects that were subsumed within existing schemes. Cities used funds from the central JNNURM to develop low-carbon public transit: Coimbatore expanded its bus network and Rajkot developed a Bus Rapid Transit system of $10.7 \mathrm{~km}$, operated by a special purpose vehicle whose slogan is "we are greener than you think." For the Solar City Programme, Rajkot adopted a 'model by-law' drawing from the guidelines in the national scheme to mandate solar water heaters for private construction above $150 \mathrm{~m} 2$ plinth area (RMC \& ICLEI SA, 2009). Partaking in the scheme allowed the city to take advantage of a financial incentive of up to $50,00,000$ INR ( 70,500 USD (2019)) provided by the centre for scheme uptake (Bhardwaj and Khosla, 2017; MNRE, 2008). 


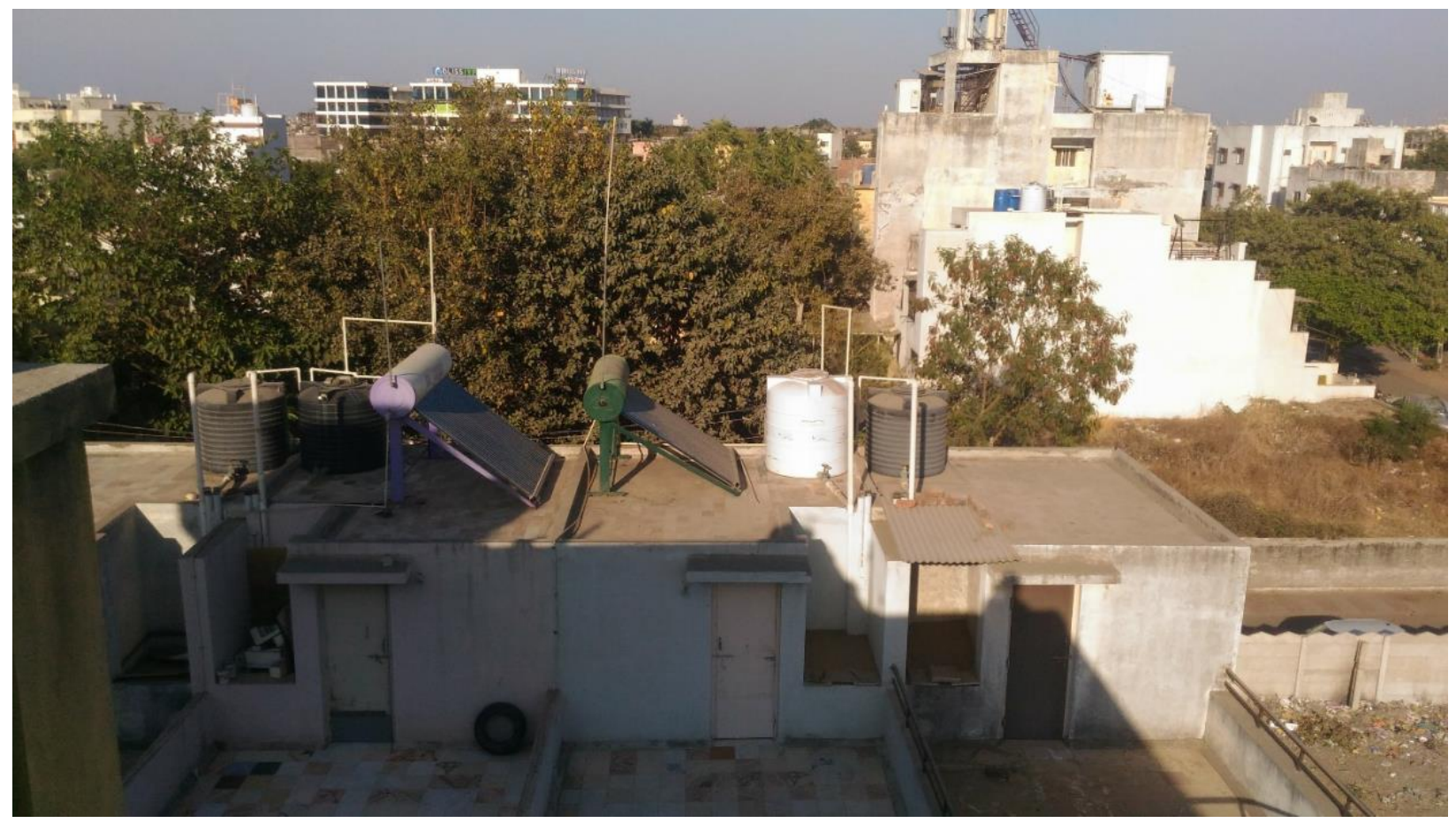

Figure 3: Solar water heaters on private rooftops in Rajkot.

In each of these cases, successful low-carbon city actions were part of existing bureaucratic incentives and did not require extending or modifying present institutional arrangements. Even when addressing a novel, complex challenge such as climate change, bureaucracies have 'path dependencies' based on existing norms, values, and interests that influence what climate responses cities pursue. For Rajkot and Coimbatore, the manner in which climate change mitigation is pursued is ultimately tied to the priorities that are set by the bureaucratic hierarchy. While a few schemes can be directly linked with climate change, as in the case of the National Solar Mission, the majority are framed in terms of urban development more broadly, as with JNNURM, in which case city officials use their discretion to incorporate climate change mitigation or adaption actions.

\section{Integrating development with climate change}


Indian city leadership is incentivized, like their equivalents in other countries, to prioritize alleviating deficits in infrastructure and increasing access and quality of urban services. In both cities, too, the foremost priorities were similar development-related objectives that correspond to those laid out in the national and state-level schemes. Climate change follows as an additional interest, either explicitly or implicitly, but at a good distance from the overarching emphasis on the conventional metrics of development to these growing cities. As a result, climate change projects are often couched and justified in development terms.

For example, in Rajkot, housing is a local development priority for which the municipal corporation dedicated considerable capacity by setting up a special cell dedicated to the delivery of housing, as part of the state and central government 'Housing for All' program. The special cell status gave the officials authority to fast track the implementation of housing. Concerned also with the climate-related stresses, city engineers in the special cell superimposed climate change objectives onto housing development schemes by including design elements like passive ventilation, rainwater harvesting tanks, and extra shading into housing plans and design. Replying to our question about how the engineers were able to add such features, the chief engineer said "it did not cost me more to lay concrete in a slightly different way." As the state's guidelines for the housing scheme, which have no mention of climate change, did not restrict cities on how they should design their housing, engineers were able to creatively add low-carbon design elements to a central and state government-funded project, at no to little additional cost. While actual costs of adding the passive design elements might have differed slightly, the engineer's remark reflected the agency that she had over design, and that small design changes, which would benefit other concerns such as climate change and water security, could be justified and feasibly funded under the existing housing scheme. Further, photovoltaics were put on the rooftops of the same buildings to enable renewable energy provision on site, with financial support from non-state actors (ICLEI South 
Asia, 2018d). This approach was influenced by knowledge sharing with Rajkot's sister city Leicester, United Kingdom, with the technical support provided by the Swiss Agency for Development and Co-operation and ICLEI-South Asia.

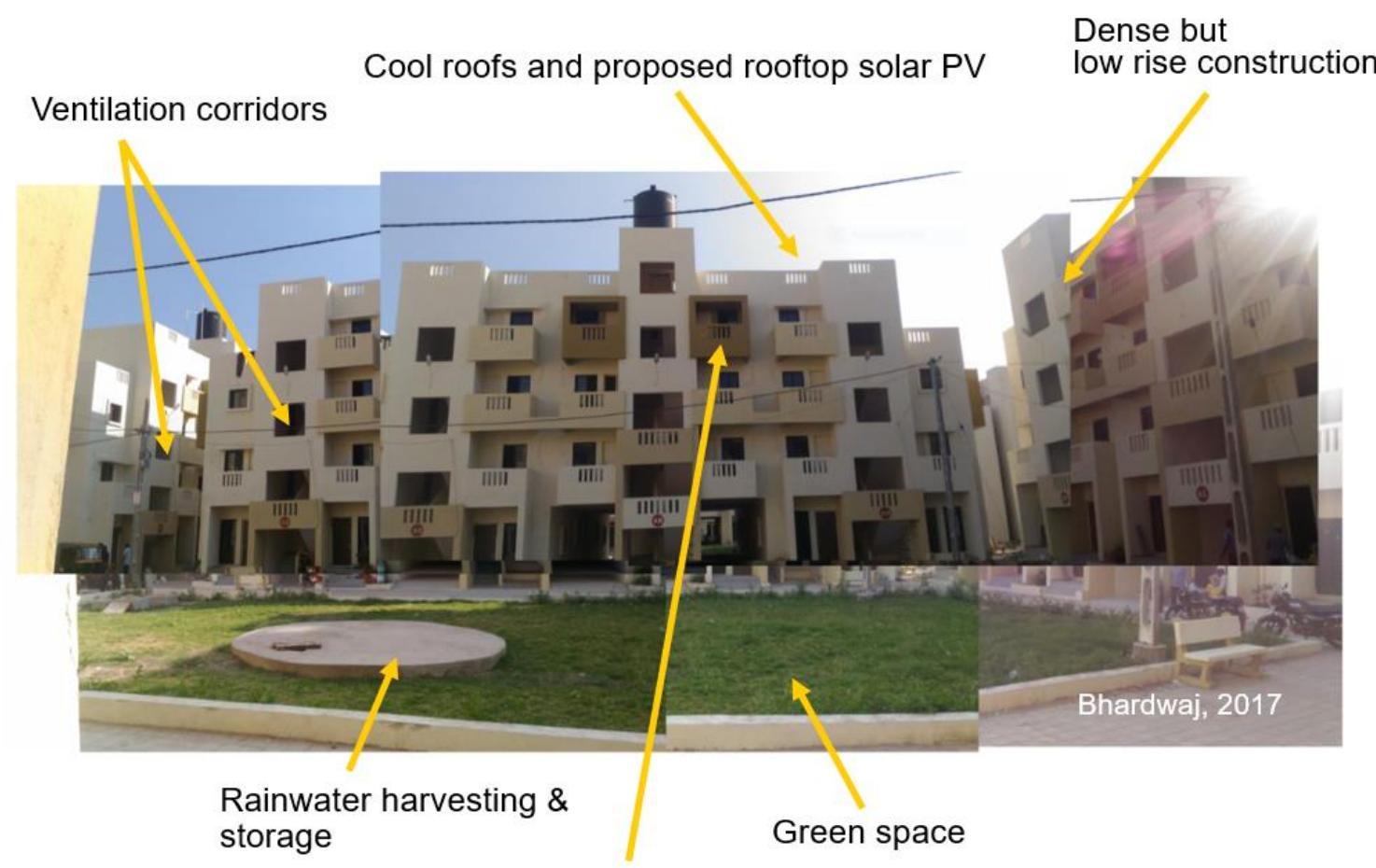

Set back windows for shade

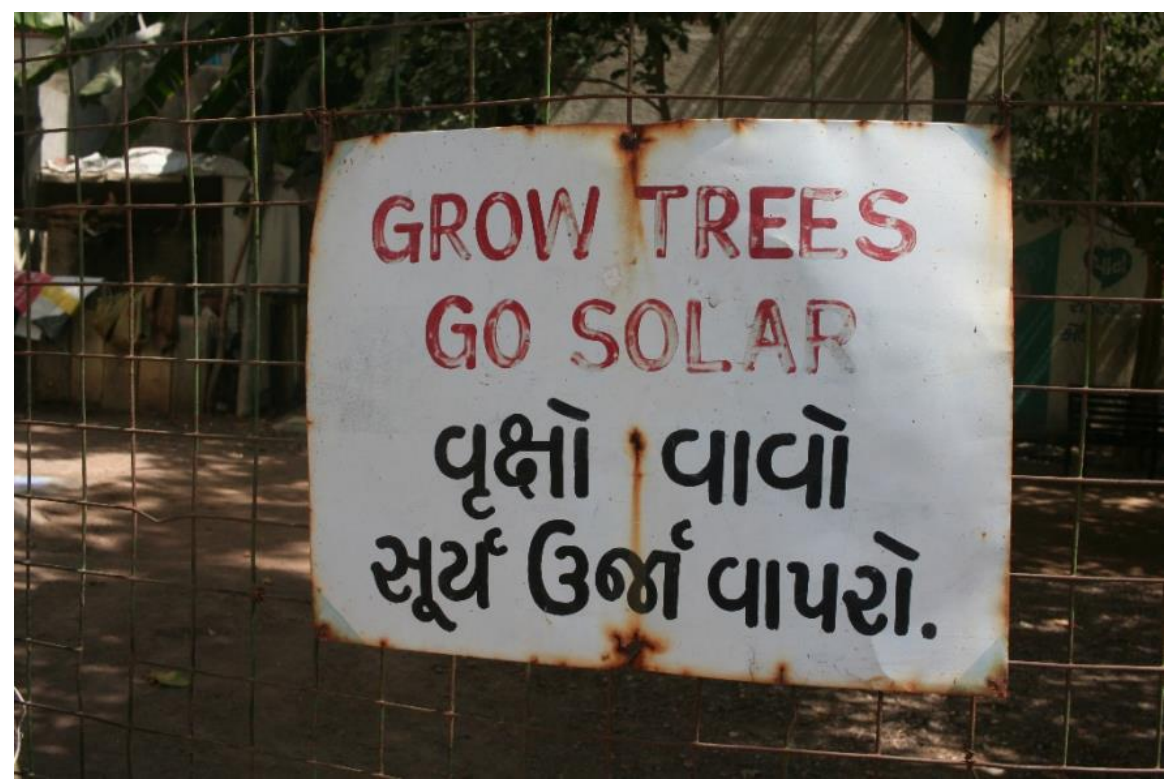


Figure 4: Affordable housing in Rajkot with climate components and ecological messaging.

Similar examples of linked climate change and development actions were observed in Coimbatore. The city aims to increase the resilience of its water supply and provide $24 / 7$ water, underscored by state-level priorities after Tamil Nadu suffered recent droughts and the capital was severely flooded in 2015. Using this development imperative, the city drew on multiple state water programs and broader national programs for basic infrastructure to bolster and restore reservoirs and lakes in and around the city. For example, the city dedicated its funds as part of the national Smart Cities Mission towards the redevelopment of seven lakes in the city's limits. Though Coimbatore's core motivation for the lake redevelopment is to increase the city's water security and treatment capacity, the plan also integrates concerns across sectors and of multiple actors, including public space upgrades, development of cycle lanes, landscape design to encourage biodiversity, and affordable housing by the lakes. The project involved the engagement of multiple actors such as officials from the water, transport, and housing departments, as well as local civil society and environmental interest groups. Coimbatore was then able to integrate concerns across sectors and actors, including climate considerations, without broad bureaucratic reform. 

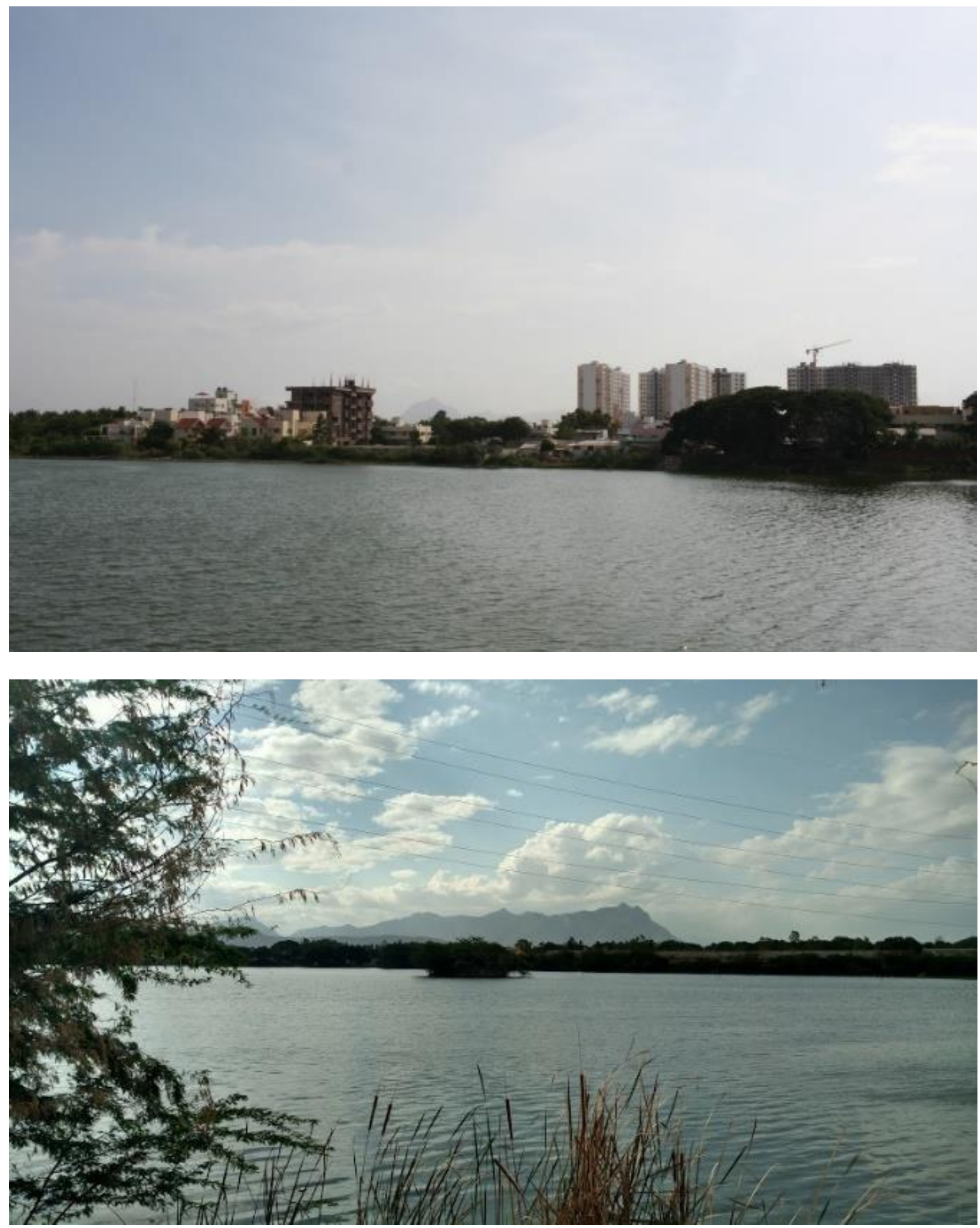


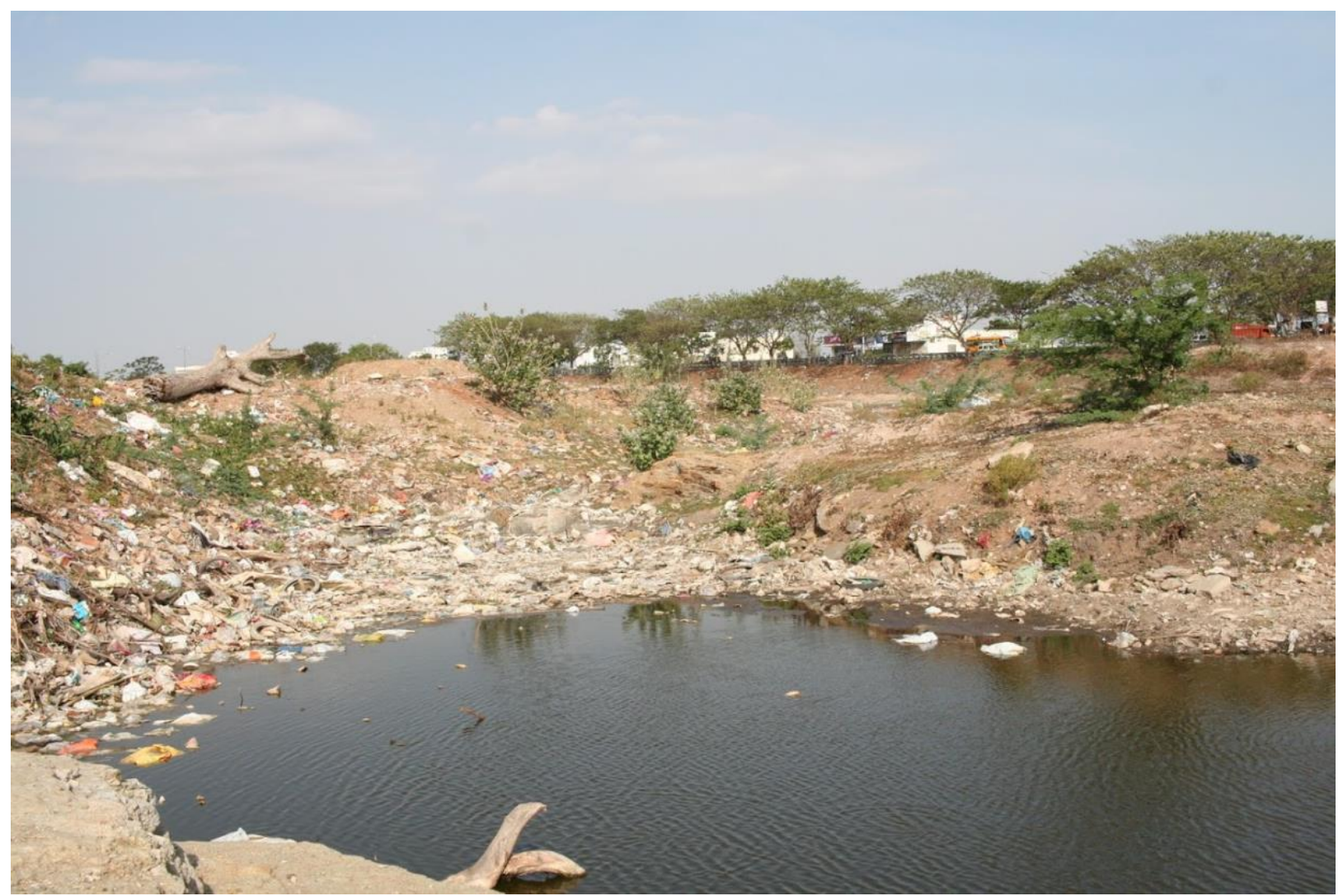

Figure 5: State of Coimbatore's multiple lakes in 2017 and 2018

Both these examples indicate the significance of nationally driven development schemes and associated resources towards achieving urban climate action, but also municipalities' agency in deciding how to spend money and resources on issues that link development and climate goals. For example, under the Housing for All program, the area per home is specified by the scheme, but their locations, materials, design, and process of construction are open parameters for city officials to decide. Bureaucrats noted that they had adequate funds to pursue actions, but sometimes lacked project vision and management capacity to get there: "we need ideas to invest in, money is not an issue" one Deputy Commissioner noted. Cities then have some control over design and siting in this multi-level arrangement, but often little capacity to act upon this control. Coimbatore's focus on the lakes as part of the national Smart Cities Mission-a scheme with little explicit ecological or climate focus-is an indication of how Indian cities can 
experiment and orient national schemes towards climate objectives. As examples from both Rajkot and Coimbatore demonstrate, the purview of existing state and central schemes is being creatively modified by entrepreneurial city officials to implement projects that address both climate change and core development priorities. In most cases, these linkages are enabled by the external support provided by climate-oriented non-state actors. Non-state actors like ICLEI, SDC and ADB brought technical climate expertise to state agencies to complement their existing skills and help create climate resilient infrastructure as part of the city's ongoing projects. This interlinking and superimposition led to a set of development actions with climate co-benefits and to a mainstreaming of climate-related concerns into the existing norms and practices of the city's functions.

Crucially, such convergence would not have been possible were it not for the "creative arbitrariness' and flexibility of planning and bureaucratic norms in the cities. City governments are one of the few institutions in India (apart from Executive offices such as the Prime Minister's or Chief Minister's Office) with a multi-sectoral mandate that can "converge" schemes and their financing, though there is no specific mandate to integrate across sectors. But, as city leaders are in charge of infrastructures that are materially interconnected, they can better identify and act upon the related synergies compared to other levels of government, which tend to govern urban infrastructures along sectoral lines. The climate-related solutions that emerge are therefore a merger of state and non-state finances and of development and climate objectives. As the housing example shows, while the project primarily used financing from the national government, and eventually reported the individual housing units built for the evaluation of the program aimed at development, the project also created a low-carbon solution by including water and energy infrastructures (mandates of other sectoral departments) in the sites. This example exhibits how Indian cities can take advantage of their 'combinatorial potential', but on a site-by-site, project-by-project basis. 


\section{Visible, bankable, and quick-win projects}

In the varied urban climate responses of Coimbatore and Rajkot, dominant bureaucratic norms mark the actions in both cities i.e. the prioritization of projects that are 'quick-wins', 'bankable', and 'visible'. First, the short-term appointments of city leaders underscores the focus on shortcycle project implementation. State bureaucracies appoint municipal commissioners who lead city governments for a term of three years, within which commissioners orient their actions to show visible achievement. City officials are motivated to act quickly and visibly to exhibit that implementation is afoot, particularly to the upper levels of bureaucracies. As a city engineer in Rajkot remarked, it is important to show that "work is happening", be it cosmetic. In Rajkot, the focus on displaying achievement of ongoing schemes incentivizes city bureaucrats to undertake projects that are visible and presentable in official statistics. As a result, climate change becomes an issue by which bureaucrats can differentiate themselves and demonstrate leadership. The commissioner between 2014 and 2016 in Rajkot was promoted to the state's Chief Minister's Office based on a track record that included implementing climate-friendly projects. Rajkot's current leadership released a full page 'advertorial' in a national newspaper emphasizing Rajkot as a climate change leader and a location for 'investment' (see Figure 6). In Coimbatore, city officials encouraged initial efforts under the Smart Cities Mission to focus on the 'quick wins'; for instance, visible public space upgrades such as shipping containers painted brightly red in public spaces were prioritized over infrastructure projects to enhance water security, biodiversity, or low-carbon mobility (bike paths). Social concerns such as affordable housing were also sidelined. 


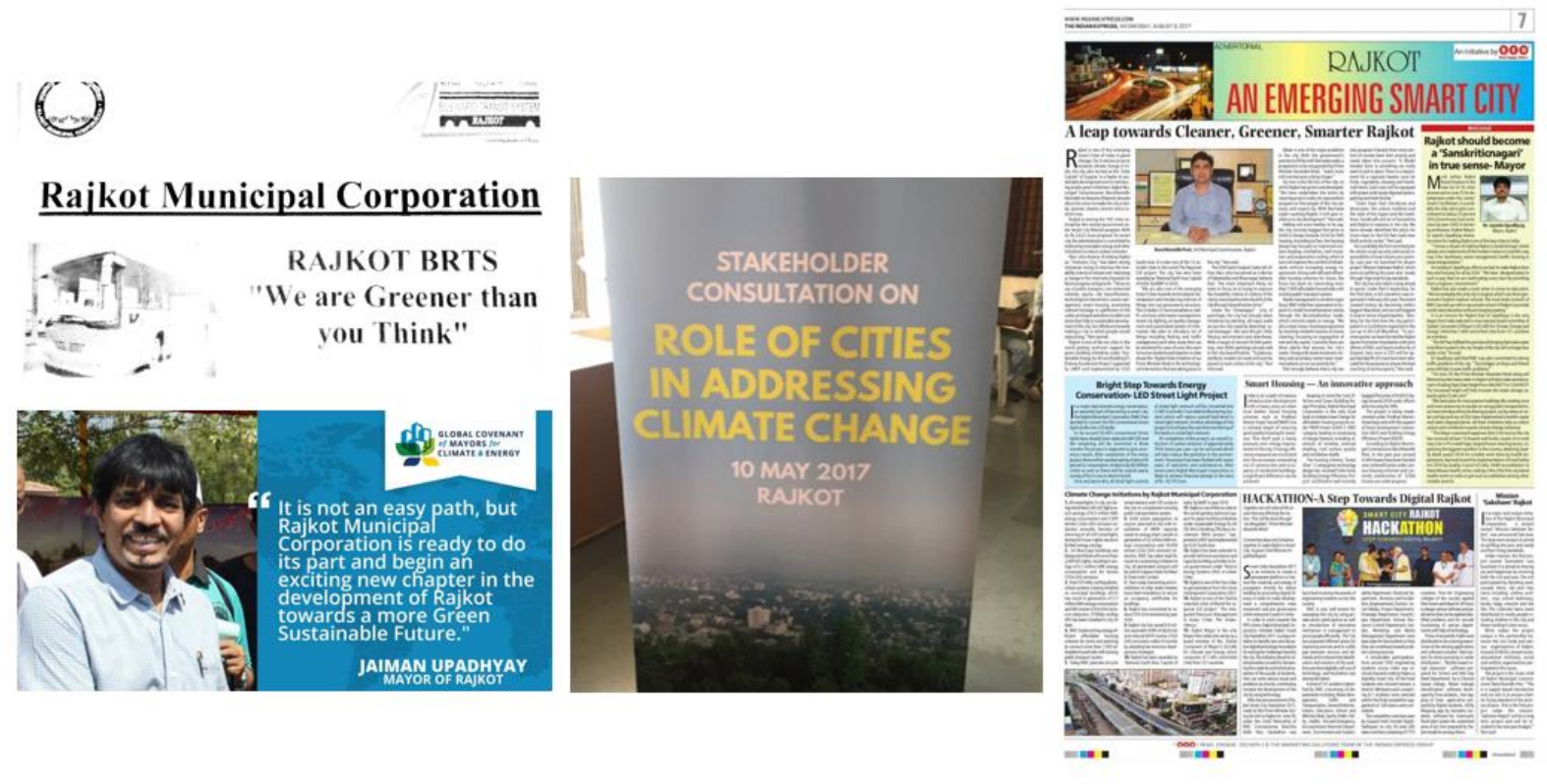

Figure 6: Rajkot's climate-based public relations; Top Left) Poster of Rajkot's Bus Rapid Transit service; Bottom Left) Social media engagement by Rajkot Mayor positioning the city as a climate champion. The Mayor of Rajkot is now part of the Global Governance of Mayors for Climate Change; Centre) Poster for a Stakeholder consultation held by the city involving civil society, municipal and state officials; Right) A full-page advertorial released by the Rajkot Municipal Corporation highlighting Rajkot's multiple climate actions towards a 'Cleaner, Greener, Smarter Rajkot'. 


\section{VALANKULAM OUERVIEW}

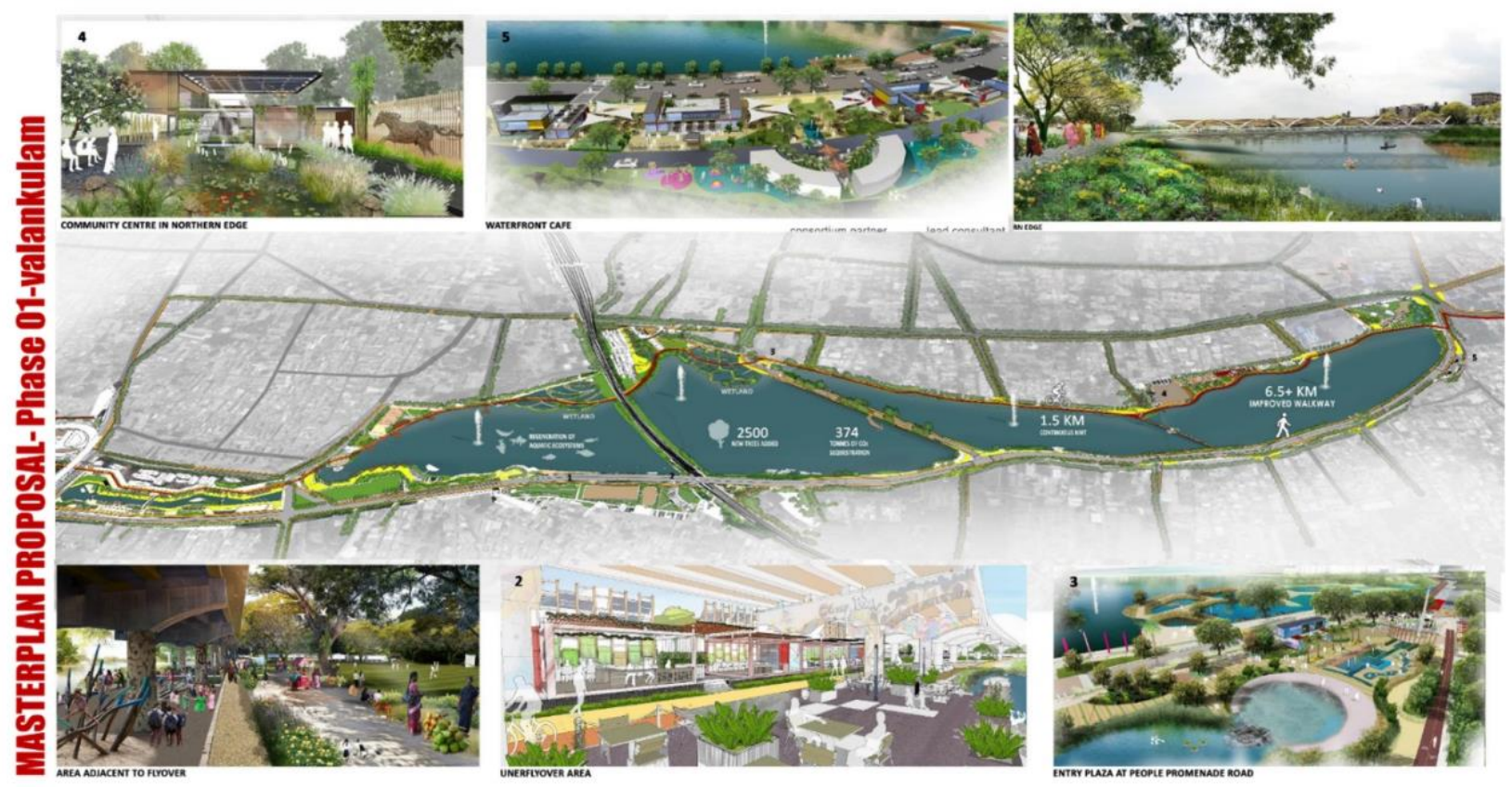

Figure 7: Plans for Coimbatore Lakes by Municipal Corporation and consultant Oasis Designs (2018)

Further, as municipalities predominantly depend on state or national funds, they face fiscal pressures and consequently emphasize focusing on projects that are 'bankable.' Since the funds received from higher levels of governance can often be inadequate for the scale and complexity of urban concerns, commissioners also seek parallel sources of financing either from private sources, loans, or by leveraging municipal assets. These characteristics are seen in the climate actions developed by both cities in 2018, with the support of ICLEI-South Asia and the Swiss Development Agency program, which involved a sector-by-sector identification of lowcarbon and resilient projects that are both 'quick wins' and 'bankable' (ICLEI South Asia, 2017a, 2017b), following a format that bureaucrats are accustomed to. As part of the program, both municipal corporations emphasized the quick wins of installing air quality monitoring stations (ICLEI South Asia, 2018a, 2018b, 2018c, 2018d, 2018d, 2019a, 2019b), rather than plans to reduce air pollution in the city itself. Non-state donors too adopted the focus on 'bankable' 
projects, emphasizing the development of feasibility studies and plans for waste, water, and transport sectors, though with little sense of how the studies and plans would influence longterm decision-making (ICLEI South Asia, 2017a, 2017b).

In another example of the focus on the 'bankable', under the National Street Lighting Mission, and with support of ICLEI under the Urban Low Emission Development Strategies program, Rajkot converted 50,000 sodium streetlights to the much more energy efficient light emitting diode (LED) bulbs. This effort was built on successful coordination with the national government's Energy Efficient Services Limited, an entity contracted by the city of Rajkot that aggregates demand of LED bulbs (Kamat et al., 2020). The city projects annual financial savings of $4 \mathrm{cr}$. INR (626,060 USD) per annum and 7 MT CO2. The city also upgraded to more efficient municipal water pumps using the same approach (Bhardwaj and Khosla, 2017).

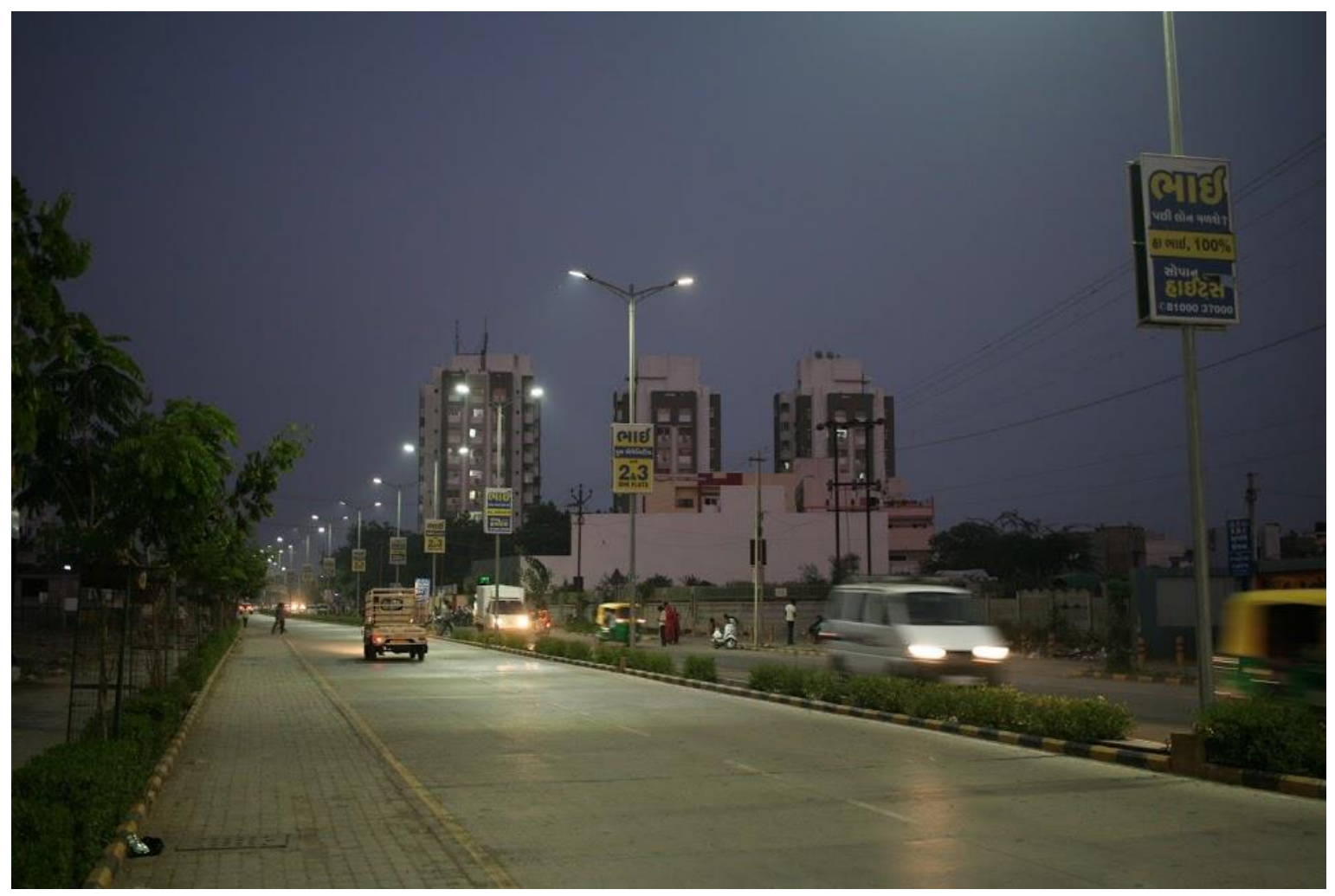

Figure 8 LED Streetlights in Rajkot converted as part of the National Street Lighting Mission. 
Such a focus on 'bankable', 'quick-win', and 'visible' projects stems from the bureaucratic cadre's understanding of city governments as "implementation agencies" with departments in “HR [Human Resources], finance and engineering," as related by the commissioner of Rajkot. Coimbatore's structure is similar (CCMC, 2015; Transparent Chennai, 2015). Both cities target urban infrastructure and service provision with a focus on implementing technical solutions and managing the necessary finances and personnel. Yet, there is little room beyond "day to day" concerns and as one city engineer noted, even if schemes have "good ideas" and funds, they are often let down by "bad implementation". Officials from both Rajkot and Coimbatore also spoke of the need for the city to improve its "management capacity". Reforms aimed at improving implementation, however, have led to the increased hiring of private sector consultants with short-term contracts and the creation of dedicated offices to expedite implementation such as 'Special Purpose Vehicles'. For example, Rajkot has designated offices to implement its schemes for creating a bus rapid transit network, management and construction of affordable housing units, among others. The officer in charge of the latter spoke highly of this arrangement as it freed her "from political interference". The national government's Smart Cities Mission reinforces this model, mandating that cities set up 'Special Purpose Vehicles' that borrow private sources of finance, ideally hire managers with private sector experience, and implement projects without other political obligations (MoUD, 2015).

The focus on implementing 'bankable', 'quick-win', and 'visible' projects creates conditions in which non-state actors, such as consultants and private service providers bid for official city contracts. This growing authority of non-state actors permeates urban governance. An institutional route often pursued is the release of contracts and tenders by city governments to which mostly private service providers respond. For example, a consultant involved in the Rajkot smart cities project summarized his role as providing "technologies and solutions for the aims of cities." He drew a strict delineation between city officials, who identified the "social" 
objectives of city actions, and his role to provide implementation support. Such consultants now form a large and mobile expert community who share technology updates and solutions through their own cross-country networks. With the involvement of consultants, the emphasis on innovative and quickly deployable technologies is reinforced. More so, the flow of funds from the city to private service providers with a resulting "contracturalisation" of city actions is part of a larger trend in Indian urban governance (Kundu, 2014; Zérah, 2009).

This is particularly the case in the monetized and informal waste economy (de Bercegol and Gowda, 2019; Doron and Jeffrey, 2018; Gidwani, 2015; Krishna et al., 2017), where the national Swachh Bharat Mission incentivizes the deployment of urban "Waste to Energy" plants and cities, with input from non-state actors, have identified the technology as one that addresses local solid waste management goals while also mitigating climate change. For example, the Coimbatore municipal corporation set up a biomethanation plant near its Vellalore landfill site. According to the plant manager, the plant has a capacity of $2 \mathrm{MW}$, processing organic waste from commercial and large residential organizations in the city and burning it to power a small biogas turbine. The residue is processed over three to four weeks into "Black Gold" —-the propriety fertilizer. Rajkot's waste processing plants are designed to create 'eco-bricks' and 'green coal' (RUDA, 2015).

\section{Perverse actions and tradeoffs of superimposition}

Rajkot and Coimbatore are finding ways to mainstream climate change in their bureaucratic practices, often by linking and superimposing climate concerns on to existing schemes. Their city leaderships identify and implement projects that simultaneously meet development objectives devised by upper levels of the bureaucracy, and climate change goals supported by non-state and state actors with technical expertise and financing. 
These bureaucratic approaches, while entrepreneurial and effective in deploying technologies, are ultimately constrained by the existing limitations of the system of urban governance. The urgency from shorter time horizons of schemes makes the demands of an integrated urban strategy and climate change's long-term implications for the city less pressing for the bureaucratic leadership. When asked about the wider social and environmental implications of ongoing projects of water and housing in the city, a municipal commissioner noted that for him, "tradeoffs are irrelevant". This was reiterated again in a public forum. Commenting on how current actions stack up in relation to future climate risks such as temperature increase and water insecurity, the commissioner remarked that "if we are going in the right path, we do not have to worry about 2030." Implicit in this statement was the prioritization of short-term goals linked to schemes over long-term concerns. By superimposing climate objectives onto existing governance arrangements and bureaucratic practices, the cities made five corresponding and systematic trade-offs (see Figure 9): 1) address objectives systematically through plans because of the focus on schemes; 2) identify and act upon tradeoffs of infrastructure development and social welfare; 3) develop and implement long-term projects to achieve 'slow wins'; 4) address everyday infrastructure upgrades because of prioritizing 'visible' projects; and 5) develop accountable service delivery because of the focus on identifying 'bankable' projects that privatize urban service delivery. We briefly explore each in turn. 


\section{Superimposition:} or how Indian cities are responding to climate change
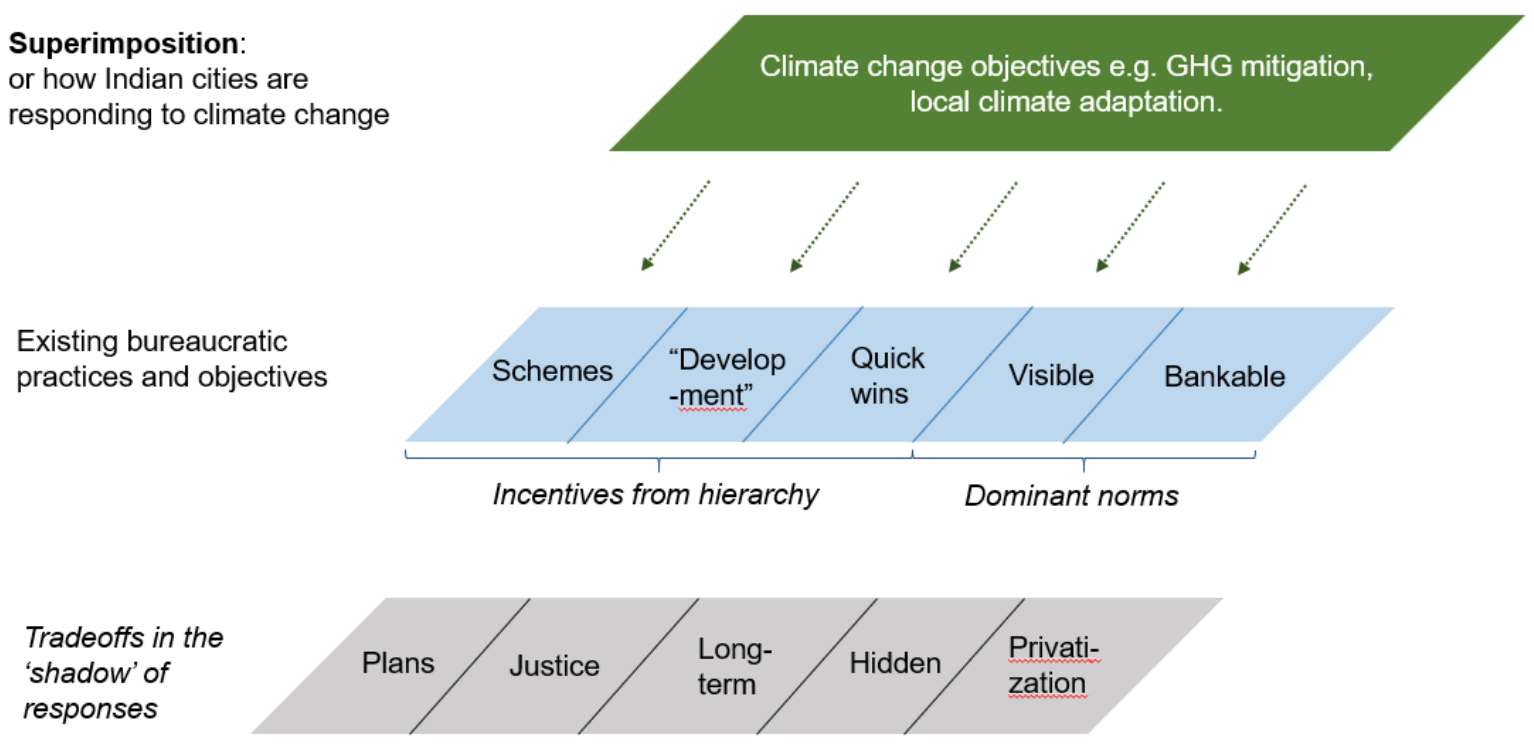

Figure 9: Tradeoffs of the superimposition approach

First, city leadership do not have incentives to plan for the long-term or across sectors. Long term, inter-sectoral, strategic planning is reflected in urban spatial plans, but these are designed by regional and town planning departments of the State, who have little financial allocations, capacity or institutional positions to co-ordinate with urban agencies. The plans, as interviewees remarked, are documents with little influence over their actual implementation (Kumar and Geneletti, 2015). As a result, long-term questions around sprawl, polluting industrial growth or security of water supply—while raised by local environmental activists-were not considered in Rajkot or Coimbatore.

An implication of being limited to schemes is the omission of incentives to address or even consider the many climate adaptation and mitigation risks that exist in the urban periphery beyond municipal jurisdictions. For example, city governments have little say in state-led projects that can drive sprawl such as special economic zones. Spatial city masterplans drawn at the larger district levels have little influence on city decision-making, and as a result neither 
city could assess the spatial implications of their ongoing projects, nor were the implications of sprawl and urban growth considered in climate-related discussions, which focused around sites such as housing projects, water pumping stations, lakes, and building rooftops. In Coimbatore, projects for water supply were implemented at both the state and city level, however with little co-ordination between local groundwater depletion and water allocations from the state's reservoirs, which could potentially exacerbate the city's water insecurity. In another example, in both Rajkot and Coimbatore, the city could not successfully govern industries that polluted their air, as this technically falls under the jurisdiction of state pollution control boards, and therefore rarely figured in local deliberations.

Second, superimposition leads city officials to identify and implement projects that have synergies between state-aligned development and climate goals, but often there are also tradeoffs with concerns of social welfare and justice. For example, to keep the costs of the housing project in Rajkot low, the housing site was located in the city's periphery where land costs were lower, but this had tradeoffs for transport accessibility and subsequent GHG emissions; the site had limited public transit access, making work commutes for residents very long. Further, the site used for affordable housing construction was previously used by farmers to graze their cattle, but there was little consideration given to farmer livelihoods in the design and implementation of the project. Therefore, while the project was for (low carbon) affordable housing for 'economically weaker sections' of society, in meeting the justice concerns of one group those of another were sidelined. Similarly, in Coimbatore, as part of the climate-friendly lake restoration projects, groups living in dwellings near the lakes were displaced (Selvam, 2019). 


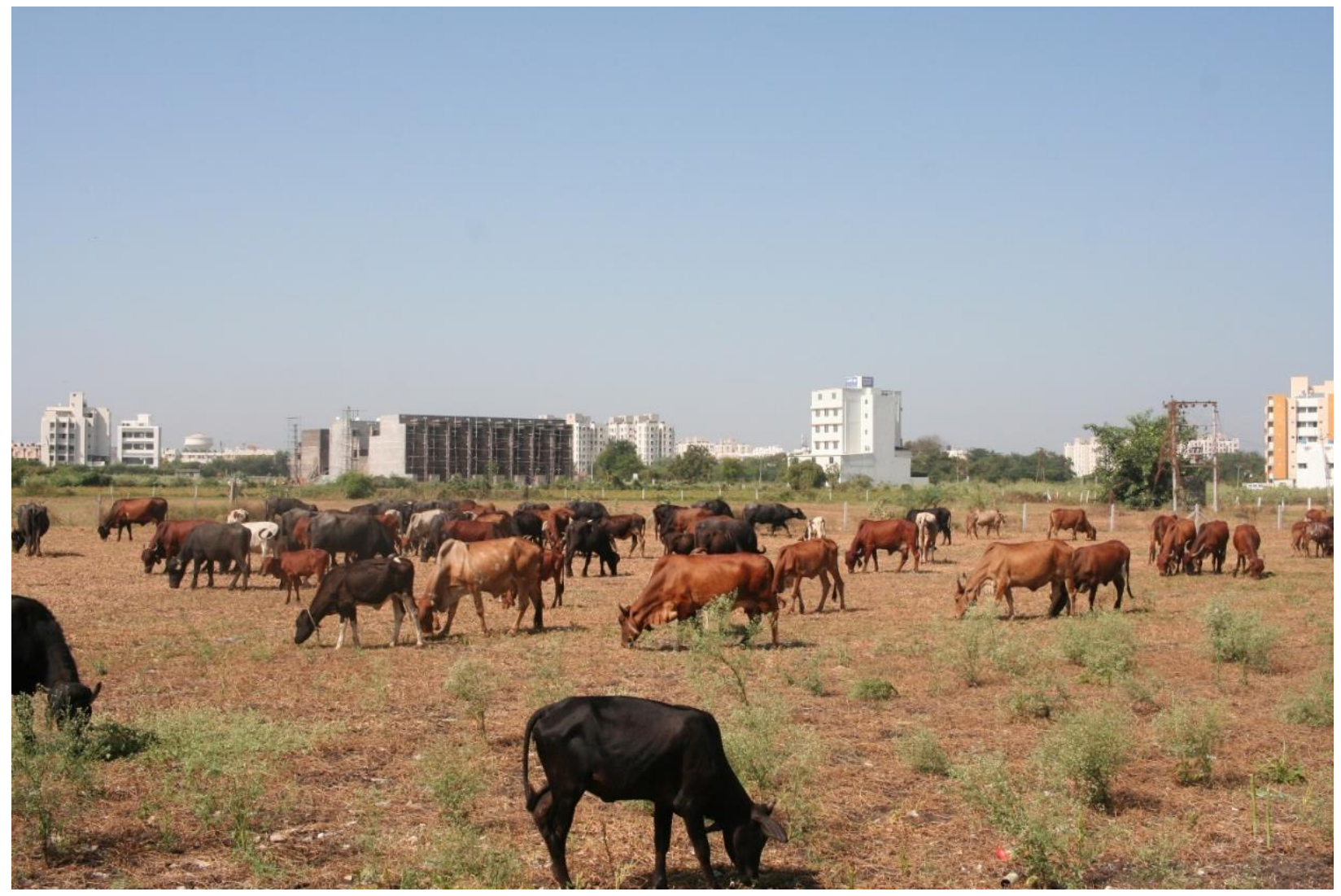

Figure 10: Cattle grazing near newly built affordable housing.

Third, the constraints within which urban climate responses are being pursued creates the burden of working within short timescales. For example, a designer involved in the ecological restoration of Coimbatore's lake emphasized that because there was pressure to show quick progress, priority was given to design elements that made progress seem visible, such as creating public spaces around lakes. However, local concerns like biodiversity and water security more aligned with addressing climate change, were left behind as they require longterm maintenance beyond the terms of individual commissioners.

Fourth, and relatedly, the approach of prioritizing viable projects reduced the imperative to pursue projects that were 'hidden' and mundane but essential towards addressing long-term climate and ecological risks. In Coimbatore, as one environmental consultant noted, less priority was given to the biodiversity of lakes as the benefits were not tangibly visible to bureaucratic 
decision-makers. In Rajkot, another local civil society activist noted that while the city was good at "presenting itself," it often let critical, mundane infrastructure such as the city's storm drainage networks enter disrepair. In the first year that Rajkot was declared the 'National Earth Capital', the lack of adequate storm drainage led to severe flooding in the city.

Fifth, the contracting of public urban infrastructure projects to address climate change to private service providers can come at the expense of accountability and long-term sustainability of the service. For example, in Coimbatore, the waste-to-energy plant was tendered out to Vardhan Infrastructure Limited (Madhavan, 2016), which an official in the city noted had connections with Tamil Nadu's Municipal Administration Minister. The state opposition party issued a memorandum to the Directorate of Vigilance and Anti-Corruption alleging misconduct by the Minister in handing out civic contracts to a host of companies owned by associates of the minister, one of them being Vardhan Infrastructure (Kaveri, 2018; The Hindu, 2018). In 2019, the opposition party, alongside other civil society NGOs, moved the state's High Court on the issue (Deccan Chronicle, 2019; The New Indian Express, 2018).

Activists in Rajkot noted that the experience with waste to energy in their city is also fraught with multiple corruption scandals around contracting. As uncovered by local activists concerned with the city's waste sector, Rajkot tendered to private companies Hanjer, then Strot, both of which reneged on the contract (Kharkhariya, 2018). As of 2019, the cases are caught in litigation, including in the National Green Tribunal (The Indian Express, 2019). The plants are furthermore operating far below capacity. Rajkot's has had past failures of private sector involvement in municipal services: the contract to run the city's buses was given to the company VITICOS to run and maintain the bus system in 2010, but in 2011 VITICOS folded, leaving the city without any functional bus transit system. These few instances indicate the growing political economy of informal contracting and corruption around low-carbon public infrastructure, where there is an often-favored set of companies with whom the city contracts. 


\section{Conclusion}

The need for urgent climate action at the city level is increasing, but often local governments, especially in the global South, have limited political mandates, inadequate for the task of marshaling multiple priorities, sectors, and actors to respond to climate change. Their existing imperatives, for example, towards development, can dominate other objectives like climate change, even though its urgency is evident. How then are such cities, with their limited ability to create new mandates and offices, addressing climate change? The Indian cities documented in this study demonstrate how a response can be fashioned by superimposing climate change objectives onto existing bureaucratic objectives and practices. The approach begins addressing climate change without needing to reform existing entrenched bureaucratic or urban planning practices. In the cases explored, this meant using existing bureaucratic schemes to finance and develop projects with climate objectives, creatively identifying linkages between development and climate objectives, and implementing projects that were politically feasible to do so. We find that such superimposition is particularly suited to climate solutions that can be deployed quickly and on a project or site basis such as solar panels or housing units with passive design elements. However, these actions have tradeoffs that are a function of the limited nature of bureaucratic incentives. Existing schemes provide little space for city leadership and engineers, motivated by bureaucratic incentives, to consider and act upon tradeoffs, long-term or justicebased concerns, or mundane dimensions of urban governance such as maintenance and hidden infrastructures.

Superimposition of climate objectives onto existing schemes is then a double-edged sword. It has many positives. It is politically tenable, it helps mainstream climate change into existing urban schemes, and it broadly results in projects that simultaneously meet development and climate objectives. In certain instances, it can create projects that are pro-poor, for example when climate objectives are aligned with a welfare policy as in the case of the low-income, low- 
carbon housing development in Rajkot. It also means that cities can begin responding to climate change with the tools available to them, within their existed limited capacities and governance arrangements as many global South cities find themselves in. But climate action through superimposition limits its overall scope and potential. It takes entrepreneurial engineers and leaders, which are few and far between, to creatively superimpose climate objectives, and yet this is only possible within the limited scope of existing jurisdictions, incentives provided by line ministries, and terms developed by incumbent bureaucrats. Other issues that do not meet these conditions, like long-term water security, existing livelihoods, transit accessibility, or air pollution are ignored. As they do not modify existing unjust planning practices, climate actions devised through superimposition have the tradeoff of reinforcing social inequalities, corrupt practices, and environmental degradation. Neither identifying politically tenable approaches, mainstreaming climate objectives into existing urban governance, nor acting upon development and climate linkages is adequate if the existing urban governance framework limits cities to simply implement units of infrastructure in isolated sites. Superimposition offers a potential approach for other similarly governed cities to formulate climate projects, but in such an arrangement scaling up or accelerating responses would involve upper levels of bureaucracy giving wider responsibilities and complementary incentives to their city governments.

Even with its limitations, the practice of superimposition by these two city governments has lessons for similarly governed cities and for future research on urban climate action. The first is the significance of non-climate schemes towards achieving climate objectives. Many of the streams and financing came from sectors which are often less discussed in terms of climate change, such as housing or waste management, but which often provide opportunities to deploy climate-friendly infrastructure at scale. The focus on non-climate schemes as a mechanism to implement climate projects also indicates the little tapped potential of formulating climate action 
by finding linkages with existing development objectives, often which bureaucracies and political actors already have strong incentives to implement.

The second is the potential creativity and agency of city bureaucracies to respond to climate change, even when they have limited capacities or mandates to reform governance practices. As seen in the cases, cities without reforming urban planning practices were able to engage multiple actors and integrate concerns across sectors as part of their existing bureaucratic practices. While this involved creative, entrepreneurial actors that operated in between bureaucratic practices, which can be rare, it does show the current potential and agency of bureaucracies to lead and experiment in responding to climate change with little independent finance.

Lastly, the cases highlighted the entrenched nature of existing bureaucratic practices and norms, which still condition the type of response possible to a novel problem like climate change. For example, in the case of India we find that the dominance of development concerns, little city-level democracy and therefore dominance of a centralized bureaucracy, and lack of independent financing influenced the course of urban climate action. Future research can focus on understanding how existing decision-making and planning practices in other settings, global South or North especially where there is limited capacity and scope for reform, are influencing the types of climate responses devised and pursued. For example, what are the implications for local housing justice or deep decarbonization, if cities superimpose low-carbon objectives on their existing housing developments? Of interest as well is how non-state, climate-concerned actors such as transnational city networks or international agencies also adapt their projects to suit existing bureaucratic practices, as was evident in the cases. While in a few occasions international non-state actors have the ability to dominate agendas, in small-to-medium cities where such actors have lesser of a role, the priorities of local bureaucratic and private actors 
can begin dominating the climate response agendas. Seeing that international non-state actors cannot be everywhere, the latter might be more indicative of urban climate action to come.

\section{Highlights}

- Case study of how two medium-size Indian cities-Rajkot and Coimbatore-are developing a response to climate change that also addresses development objectives.

- Develops the concept of "superimposition" to identify how cities can respond to climate change without reforming existing bureaucratic practices, emphasizing the need to understand the political arrangements cities are embedded in to understand their scope of ambition.

- Identifies five characteristics of city bureaucracies that limit the scope of climate action: 1) the primacy of central and state 'schemes'; 2) the prioritization of 'development' as an objective; and the imperative to implement 3) 'quick win', 4) 'visible', and 5) 'bankable' projects.

- Shows that "superimposition" as done by Indian cities responding to climate change can have systemic tradeoffs of long-term planning, urban justice, and public ownership of infrastructure.

\section{Conflict of interest}

The authors declare no conflicts of interest.

\section{References}

Acuto M (2012) Ain't about politics? The wicked power-geometry of Sydney's greening governance. International Journal of Urban and Regional Research 36(2): 381-399.

Acuto M (2013) Global Cities, Governance and Diplomacy: The Urban Link. Routledge.

Acuto M and Parnell S (2016) Leave no city behind. Science 352(6288): 873-873. DOI: 10.1126/science.aag1385. 
Acuto M, Parnell S and Seto KC (2018) Building a global urban science. Nature Sustainability 1(1): 2-4. DOI: 10.1038/s41893-017-0013-9.

Aggarwal RM (2013) Strategic Bundling of Development Policies with Adaptation- An Examination of Delhi's Climate Change Action Plan. International Journal of Urban and Regional Research.

Ahluwalia IJ (2017) Urban governance in India. Journal of Urban Affairs: 1-20.

Amin A and Thrift N (2016) Seeing Like a City. Cambridge, UK; Malden, MA: Polity Press.

Andonova LB, Hale TN and Roger CB (2017) National policy and transnational governance of climate change: Substitutes or complements? International Studies Quarterly 61(2): 253-268.

Andrews M, Woolcock M and Pritchett L (2017) Building State Capability: Evidence, Analysis, Action. Oxford University Press.

Angelo $\mathrm{H}$ and Wachsmuth $\mathrm{D}$ (2015) Urbanizing urban political ecology: A critique of methodological cityism. International Journal of Urban and Regional Research 39(1): 16-27.

Anguelovski I and Carmin J (2011) Something borrowed, everything new: innovation and institutionalization in urban climate governance. Current opinion in environmental sustainability 3(3): 169-175.

Anguelovski I, Chu E and Carmin J (2014) Variations in approaches to urban climate adaptation: Experiences and experimentation from the global South. Global Environmental Change 27: 156-167.

Anguelovski I, Irazábal-Zurita C and Connolly JJT (2019) Grabbed Urban Landscapes: Sociospatial Tensions in Green Infrastructure Planning in Medellín. International Journal of Urban and Regional Research 43(1): 133-156. DOI: 10.1111/1468-2427.12725.

Aylett A (2010) 10 Municipal bureaucracies and integrated urban transitions to a low carbon future. Cities and Low Carbon Transitions: 142.

Aylett A (2013) The Socio-institutional Dynamics of Urban Climate Governance: A Comparative Analysis of Innovation and Change in Durban (KZN, South Africa) and Portland (OR, USA). Urban Studies 50(7): 1386-1402. DOI: 10.1177/0042098013480968.

Aylett A (2014) Progress and Challenges in the Urban Governance of Climate Change: Results of a Global Survey. MIT.

Bai X, Surveyer A, Elmqvist T, et al. (2016) Defining and advancing a systems approach for sustainable cities. Current Opinion in Environmental Sustainability 23: 69-78. DOI: 10.1016/j.cosust.2016.11.010.

Bai X, Dawson RJ, Ürge-Vorsatz D, et al. (2018) Six research priorities for cities and climate change. Nature 555(7694): 23-25. DOI: 10.1038/d41586-018-02409-z. 
Barber BR (2013) If Mayors Ruled the World: Dysfunctional Nations, Rising Cities. Yale University Press.

Basu S, Bale CS, Wehnert T, et al. (2019) A complexity approach to defining urban energy systems. Cities 95: 102358.

Beck U (1992) Risk Society: Towards a New Modernity. First edition. London; Newbury Park, Calif: SAGE Publications Ltd.

Bellinson R and Chu E (2019) Learning pathways and the governance of innovations in urban climate change resilience and adaptation. Journal of Environmental Policy \& Planning 21(1): 76-89.

Betsill MM and Bulkeley H (2004) Transnational networks and global environmental governance: The cities for climate protection program. International studies quarterly 48(2): 471-493.

Bhardwaj A and Khosla R (2017) Mainstreaming climate action in Indian cities: Case study of Rajkot. Policy Brief. New Delhi: Centre for Policy Research.

Bhardwaj A and Khosla R (2018) Integrating Urban Development and Climate Objectives: Insights from Coimbatore. Policy Brief. New Delhi: Centre for Policy Research.

Bhardwaj A, Joshi M, Khosla R, et al. (2019) More priorities, more problems? Decision-making with multiple energy, development and climate objectives. Energy Research \& Social Science 49: 143-157. DOI: 10.1016/j.erss.2018.11.003.

Birkmann J, Welle T, Solecki W, et al. (2016) Boost resilience of small and mid-sized cities. Nature 537: 605-608.

Blok A (2016) Assembling urban riskscapes: Climate adaptation, scales of change and the politics of expertise in Surat, India. City 20(4): 602-618.

Borie M, Pelling M, Ziervogel G, et al. (2019) Mapping narratives of urban resilience in the global south. Global Environmental Change 54: 203-213.

Bouteligier S (2012) Cities, Networks, and Global Environmental Governance: Spaces of Innovation, Places of Leadership. Routledge.

Boyd E and Ghosh A (2013) Innovations for Enabling Urban Climate Governance: Evidence from Mumbai. Environment and Planning C: Government and Policy 31(5): 926-945. DOI: $10.1068 / \mathrm{c} 12172$.

Braun BP (2014) A new urban dispositif? Governing life in an age of climate change. Environment and Planning D: Society and Space 32(1): 49-64.

Broto VC (2017) Energy landscapes and urban trajectories towards sustainability. Energy Policy. DOI: 10.1016/j.enpol.2017.01.009.

Bulkeley H and Castán Broto V (2014) Urban experiments and climate change: securing zero carbon development in Bangalore. Contemporary Social Science 9(4): 393-414. 
Carmin J, Anguelovski I and Roberts D (2012) Urban climate adaptation in the global south: planning in an emerging policy domain. Journal of Planning Education and Research 32(1): 18-32.

Castán Broto V (2017) Urban Governance and the Politics of Climate change. World Development 93: 1-15. DOI: 10.1016/j.worlddev.2016.12.031.

Castán Broto V and Bulkeley H (2013) A survey of urban climate change experiments in 100 cities. Global Environmental Change 23(1): 92-102.

CCMC (2015) Smart City Proposal. Coimbatore: Coimbatore City Muncipal Corporation.

Chu E (2016) The political economy of urban climate adaptation and development planning in Surat, India. Environment and Planning C: Government and Policy 34(2): 281-298. DOI: 10.1177/0263774X15614174.

Chu EK (2018) Transnational support for urban climate adaptation: Emerging forms of agency and dependency. Global Environmental Politics 18(3): 25-46.

Cook MJ and Chu EK (2018) Between Policies, Programs, and Projects: How Local Actors Steer Domestic Urban Climate Adaptation Finance in India. In: Climate Change in Cities. Springer, pp. 255-277.

Cornea NL, Véron R and Zimmer A (2017) Everyday governance and urban environments: Towards a more interdisciplinary urban political ecology. Geography Compass 11(4): e12310.

de Bercegol R and Gowda S (2019) A new waste and energy nexus? Rethinking the modernisation of waste services in Delhi. Urban Studies 56(11): 2297-2314. DOI: $10.1177 / 0042098018770592$.

Deccan Chronicle (2019) Plea to register FIR against SP Velumani. Available at: https://www.deccanchronicle.com/nation/current-affairs/050119/plea-to-register-firagainst-sp-velumani.html (accessed 28 October 2019).

Denis E and Zérah M-H (eds) (2017) Subaltern Urbanisation in India: An Introduction to the Dynamics of Ordinary Towns. 1st ed. 2017 edition. New York, NY: Springer.

Dholakia HH, Mishra V and Garg A (2015) Predicted increases in heat related mortality under climate change in urban India. WP2015-05-02, IIMA Working Paper. Ahmedabad, India: Indian Institute of Management Ahmedabad, Research and Publication Department.

Doll CNH and Puppim de Oliveira JA (eds) (2017) Urbanization and Climate Co-Benefits: Implementation of Win-Win Interventions in Cities. 1 edition. London ; New York: Routledge.

Doron A and Jeffrey R (2018) Waste of a Nation - Garbage and Growth in India. Cambridge, Massachusetts: Harvard University Press.

Eadson W (2012) Constructions of the carbon city. The future of sustainable cities: 65-86. 
Engerman DC (2018) The Price of Aid. Harvard University Press.

Fisher DR and Leifeld P (2019) The polycentricity of climate policy blockage. Climatic Change. DOI: $10.1007 / \mathrm{s} 10584-019-02481-y$.

Fisher S (2012) Policy storylines in Indian climate politics: opening new political spaces? Environment and Planning C: Government and Policy 30(1): 109-127. DOI: $10.1068 / \mathrm{c} 10186$.

Fisher S (2014) Exploring nascent climate policies in Indian cities: a role for policy mobilities? International Journal of Urban Sustainable Development 6(2): 154-173. DOI: 10.1080/19463138.2014.892006.

Fisher S, Dodman D, Van Epp M, et al. (2018) The usability of climate information in subnational planning in India, Kenya and Uganda: the role of social learning and intermediary organisations. Climatic Change 151(2): 219-245.

Fragkias M and Boone CG (2016) Modern political economy, global environmental change and urban sustainability transitions. Current opinion in environmental sustainability 22: 6368.

Frame B (2008) 'Wicked', 'Messy', and 'Clumsy': Long-Term Frameworks for Sustainability. Environment and Planning C: Government and Policy 26(6): 1113-1128. DOI: $10.1068 / \mathrm{c} 0790 \mathrm{~s}$.

Freeman R and Yearworth M (2017) Climate change and cities: problem structuring methods and critical perspectives on low-carbon districts. Energy Research \& Social Science 25: 48-64. DOI: 10.1016/j.erss.2016.11.009.

Fünfgeld $\mathrm{H}$ (2015) Facilitating local climate change adaptation through transnational municipal networks. Current Opinion in Environmental Sustainability 12: 67-73.

Gandhi S and Pethe A (2017) Emerging challenges of metropolitan governance in India. Economic \& Political Weekly 52(27): 55.

Ghertner DA (2015) Rule by Aesthetics: World-Class City Making in Delhi. First edition. Oxford University Press.

Gidwani V (2015) The work of waste: inside India's infra-economy. Transactions of the Institute of British Geographers 40(4): 575-595. DOI: 10.1111/tran.12094.

Goh K (2019) Flows in formation: The global-urban networks of climate change adaptation. Urban Studies: 0042098018807306. DOI: 10.1177/0042098018807306.

Gordon DJ (2016) The politics of accountability in networked urban climate governance. Global Environmental Politics 16(2): 82-100.

Gordon DJ (2018) Global urban climate governance in three and a half parts: Experimentation, coordination, integration (and contestation). Wiley Interdisciplinary Reviews: Climate Change 9(6): e546. DOI: 10.1002/wcc.546. 
Government of India (2011) Populations Census 2011. New Delhi: Census Organization of India.

Gururani S (2013) Flexible Planning: The Making of India's 'Millennium City,'Gurgaon. In: Ecologies of Urbanism in India. Hong Kong University Press.

Harrison T and Kostka G (2018) Bureaucratic manoeuvres and the local politics of climate change mitigation in China and India. Development Policy Review.

Head BW and Alford J (2015) Wicked Problems: Implications for Public Policy and Management. Administration \& Society 47(6): 711-739. DOI: $10.1177 / 0095399713481601$.

Heinrichs D, Krellenberg K and Fragkias M (2013) Urban Responses to Climate Change: Theories and Governance Practice in Cities of the Global S outh. International Journal of Urban and Regional Research 37(6): 1865-1878.

Hodson M, Geels FW and McMeekin A (2017) Reconfiguring Urban Sustainability Transitions, Analysing Multiplicity. Sustainability 9(2): 299. DOI: 10.3390/su9020299.

Hughes S (2017) The politics of urban climate change policy: Toward a research agenda. Urban Affairs Review 53(2): 362-380.

Hughes S and Romero-Lankao P (2014) Science and institution building in urban climatechange policymaking. Environmental Politics 23(6): 1023-1042. DOI: 10.1080/09644016.2014.921459.

Hulme M (2009) Why We Disagree about Climate Change: Understanding Controversy, Inaction and Opportunity. 4th Edition edition. Cambridge, UK; New York: Cambridge University Press.

Hulme M (2010) Cosmopolitan Climates: Hybridity, Foresight and Meaning. Theory, Culture and Society 27(2-3): 267-276.

ICLEI South Asia (2017a) City Climate Profile - Coimbatore. New Delhi: Swiss Agency for Development and Cooperation SDC, CapaCITIES, Coimbatore City Municipal Corporation, South Pole, ICLEI Local Governments for Sustainability, South Asia, Econcept.

ICLEI South Asia (2017b) City Climate Profile - Rajkot. New Delhi: Swiss Agency for Development and Cooperation SDC, CapaCITIES, Rajkot Municipal Corporation, South Pole, ICLEI Local Governments for Sustainability, South Asia, Econcept.

ICLEI South Asia (2017c) Second Instalment of the Climate Action Plan Workshop for CapaCITIES Project - Coimbatore. Available at: http://southasia.iclei.org/newsdetails/article/second-instalment-of-the-climate-actionplan-workshop-for-capacities-project-coimbatore.html (accessed 28 October 2019).

ICLEI South Asia (2018a) Quick Win Project - Rajkot Ambient Air Quality Monitoring Station (AAQMS). New Delhi: Swiss Agency for Development and Cooperation SDC, 
CapaCITIES, Rajkot Municipal Corporation, South Pole, ICLEI Local Governments for Sustainability, South Asia, Econcept.

ICLEI South Asia (2018b) Quick Win Project - Rajkot Ground Water Recharge System. New Delhi: Swiss Agency for Development and Cooperation SDC, CapaCITIES, Rajkot Municipal Corporation, South Pole, ICLEI Local Governments for Sustainability, South Asia, Econcept.

ICLEI South Asia (2018c) Quick Win Project - Rajkot Renewable Energy Deployment at RMC's Aji Water Treatment Plant. New Delhi: Swiss Agency for Development and Cooperation SDC, CapaCITIES, Rajkot Municipal Corporation, South Pole, ICLEI Local Governments for Sustainability, South Asia, Econcept.

ICLEI South Asia (2018d) Quick Win Project - Rajkot Solar PV in Social Housing. New Delhi: Swiss Agency for Development and Cooperation SDC, CapaCITIES, Rajkot Municipal Corporation, South Pole, ICLEI Local Governments for Sustainability, South Asia, Econcept.

ICLEI South Asia (2019a) Quick Win Project - Coimbatore Ambient Air Quality Monitoring Station (AAQMS). New Delhi: Swiss Agency for Development and Cooperation SDC, CapaCITIES, Coimbatore City Municipal Corporation, South Pole, ICLEI Local Governments for Sustainability, South Asia, Econcept.

ICLEI South Asia (2019b) Quick Win Project - Coimbatore SUNYA - Towards Zero Waste. New Delhi: Swiss Agency for Development and Cooperation SDC, CapaCITIES, Coimbatore City Municipal Corporation, South Pole, ICLEI Local Governments for Sustainability, South Asia, Econcept.

Jabareen Y (2013) Planning the resilient city: Concepts and strategies for coping with climate change and environmental risk. Cities 31: 220-229. DOI: 10.1016/j.cities.2012.05.004.

Jerolmack C and Khan S (2014) Talk is cheap: Ethnography and the attitudinal fallacy. Sociological Methods \& Research 43(2): 178-209.

Johnson C, Toly N and Schroeder H (eds) (2017) The Urban Climate Challenge: Rethinking the Role of Cities in the Global Climate Regime. 1 edition. London; New York: Routledge.

Jonas AE and While A (2007) Greening the entrepreneurial city. The sustainable development paradox: Urban political economy in the United States and Europe: 123-159.

Jones S (2018) City Governments, Climate Change, and the Performance Agenda. In: Jones S (ed.) Cities Responding to Climate Change: Copenhagen, Stockholm and Tokyo. Cham: Springer International Publishing, pp. 57-104. DOI: 10.1007/978-3-319-64810-1_3.

Jones S (2019) City governments measuring their response to climate change. Regional Studies 53(1): 146-155.

Kamat AS, Khosla R and Narayanamurti V (2020) Illuminating homes with LEDs in India: Rapid market creation towards low-carbon technology transition in a developing country. Energy Research \& Social Science 66: 101488. DOI: 10.1016/j.erss.2020.101488. 
Kameo N (2015) Gifts, donations, and loose coupling: responses to changes in academic entrepreneurship among bioscientists in Japan. Theory and Society 44(2): 177-198. DOI: $10.1007 / \mathrm{s} 11186-015-9248-5$.

Karanth A and Archer D (2014) Institutionalising mechanisms for building urban climate resilience: experiences from India. Development in Practice 24(4): 514-526. DOI: 10.1080/09614524.2014.911246.

Kaveri M (2018) Govt contracts to brother, friends: The allegations against TN minister SP Velumani. Available at: https://www.thenewsminute.com/article/govt-contracts-brotherfriends-allegations-against-tn-minister-sp-velumani-88034 (accessed 28 October 2019).

Khan S, Taraporevala P and Zérah M-H (2018) Mission Impossible: Defining Indian Smart Cities. Economic and Political Weekly 53(49): 7-8.

Kharkhariya $\mathrm{Ni}$ (2018) Lack of technical expert hampers waste-to-energy project progress. Available at: https://timesofindia.indiatimes.com/city/rajkot/lack-of-technical-experthampers-waste-to-energy-project-progress/articleshow/63964438.cms (accessed 28 October 2019).

Khosla R and Bhardwaj A (2018) Urbanization in the time of climate change: Examining the response of Indian cities. Wiley Interdisciplinary Reviews: Climate Change: e560. DOI: $10.1002 /$ wcc.560.

Khosla R, Sagar A and Mathur A (2017) Deploying Low-carbon Technologies in Developing Countries: A view from India's buildings sector. Environmental Policy and Governance 27(2): 149-162.

Klingebiel S, Mahn T and Negre M (eds) (2016) The Fragmentation of Aid: Concepts, Measurements and Implications for Development Cooperation. 1st ed. 2016 edition. London: Palgrave Macmillan.

Knox-Hayes J (2015) Towards a moral socio-environmental economy: A reconsideration of values. Geoforum 65: 297-300. DOI: 10.1016/j.geoforum.2015.07.028.

Knox-Hayes $\mathrm{J}$ and Hayes $\mathrm{J}$ (2014) Technocratic norms, political culture and climate change governance. Geografiska Annaler: Series B, Human Geography 96(3): 261-276.

Koehn PH (2008) Underneath Kyoto: Emerging Subnational Government Initiatives and Incipient Issue-Bundling Opportunities in China and the United States. Global Environmental Politics 8(1): 53-77. DOI: 10.1162/glep.2008.8.1.53.

Koslov L (2019) Avoiding Climate Change: "Agnostic Adaptation" and the Politics of Public Silence. Annals of the American Association of Geographers 109(2): 568-580. DOI: 10.1080/24694452.2018.1549472.

Kousky C and Schneider SH (2003) Global climate policy: will cities lead the way? Climate Policy 3(4): 359-372. DOI: 10.1016/j.clipol.2003.08.002. 
Krishna G, 2017 and Am 11:45 (2017) In India, critics assail proposal to build 100 waste-fueled power plants. Available at: https://www.sciencemag.org/news/2017/06/india-criticsassail-proposal-build-100-waste-fueled-power-plants (accessed 18 July 2019).

Kumar P and Geneletti D (2015) How are climate change concerns addressed by spatial plans? An evaluation framework, and an application to Indian cities. Land Use Policy 42: 210226.

Kundu D (2014) Urban Development Programmes in India: A Critique of JnNURM. Social Change 44(4): 615-632. DOI: 10.1177/0049085714548546.

Lamb WF, Creutzig F, Callaghan MW, et al. (2019) Learning about urban climate solutions from case studies. Nature Climate Change 9(4): 279. DOI: 10.1038/s41558-019-0440-x.

Leck $\mathrm{H}$ and Roberts D (2015) What lies beneath: understanding the invisible aspects of municipal climate change governance. Current Opinion in Environmental Sustainability 13: 61-67. DOI: 10.1016/j.cosust.2015.02.004.

Lee T (2012) Global Cities and Transnational Climate Change Networks. Global Environmental Politics 13(1): 108-127. DOI: 10.1162/GLEP_a_00156.

Lele S, Srinivasan V, Thomas BK, et al. (2018) Adapting to climate change in rapidly urbanizing river basins: insights from a multiple-concerns, multiple-stressors, and multi-level approach. Water International 43(2): 1-24.

Long J and Rice JL (2019) From sustainable urbanism to climate urbanism. Urban Studies 56(5): 992-1008.

Luque-Ayala A, Marvin S and Bulkeley H (eds) (2018) Rethinking Urban Transitions: Politics in the Low Carbon City. 1 edition. Abingdon, Oxon ; New York: Routledge.

Madhavan K (2016) Corporation's organic waste processing does well. The Hindu, 19 July. Coimbatore: Available at:

https://www.thehindu.com/news/cities/Coimbatore/Corporation\%E2\%80\%99s-organicwaste-processing-does-well/article14497573.ece (accessed 28 October 2019).

McGuirk PM, Bulkeley H and Dowling R (2016) Configuring Urban Carbon Governance: Insights from Sydney, Australia. Annals of the American Association of Geographers 106(1): 145-166. DOI: 10.1080/00045608.2015.1084670.

Meyer JW and Rowan B (1977) Institutionalized organizations: Formal structure as myth and ceremony. American journal of sociology 83(2). University of Chicago Press: 340-363.

MNRE (2008) MNRE Programme on 'Development of Solar Cities' Guidelines for preparing master plan as per the prescribed format of MNRE. New Delhi: Ministry of New and Renewable Energy.

MoUD (2015) Smart Cities: Mission Statement \& Guidelines. New Delhi: Ministry of Urban Development.

Muller JZ (2019) The Tyranny of Metrics. Reprint edition. Princeton University Press. 
Nagendra H, Bai X, Brondizio ES, et al. (2018) The urban south and the predicament of global sustainability. Nature Sustainability 1(7): 341.

Nandi S and Gamkhar S (2013) Urban challenges in India: A review of recent policy measures. Habitat International 39: 55-61.

Oasis Designs (2018) Eco-Restoration of 8 Lakes, Coimbatore Smart City. Available at: http://oasisdesigns.org/cecocoimbatore.asp (accessed 17 November 2019).

Patterson JJ and Huitema D (2019) Institutional innovation in urban governance: The case of climate change adaptation. Journal of Environmental Planning and Management 62(3): 374-398. DOI: 10.1080/09640568.2018.1510767.

Rajashekariah K (2011) The Impact of Urbanisation on Biodiversity: Case Studies from India. New Delhi, India: World Wildlife Foundation.

Rice JL (2010) Climate, carbon, and territory: greenhouse gas mitigation in Seattle, Washington. Annals of the Association of American Geographers 100(4): 929-937.

Rice JL, Cohen DA, Long J, et al. (2019) Contradictions of the Climate-Friendly City: New Perspectives on Eco-Gentrification and Housing Justice. International Journal of Urban and Regional Research. DOI: DOI:10.1111/1468-2427.12740.

Rittel HWJ and Webber MM (1973) Dilemmas in a general theory of planning. Policy Sciences 4(2): 155-169. DOI: 10.1007/BF01405730.

RMC \& ICLEI SA (2009) Development of Rajkot Solar City. Rajkot: Ministry of New and Renewable Energy.

Roberts D (2008) Thinking globally, acting locally — institutionalizing climate change at the local government level in Durban, South Africa. Environment and Urbanization 20(2): 521537. DOI: $10.1177 / 0956247808096126$.

Robinson J and Roy A (2016) Debate on Global Urbanisms and the Nature of Urban Theory. International Journal of Urban and Regional Research 40(1): 181-186. DOI: 10.1111/1468-2427.12272.

Romero-Lankao P, Bulkeley $\mathrm{H}$, Pelling M, et al. (2018) Urban transformative potential in a changing climate. Nature Climate Change 8(9): 754.

Rosenzweig C, Solecki W, Hammer SA, et al. (2010) Cities lead the way in climate-change action. Nature 467(7318): 909.

Roy A (2009) The 21st-Century Metropolis: New Geographies of Theory. Regional Studies 43(6): 819-830. DOI: 10.1080/00343400701809665.

RUDA (2015) Comprehensive Development Plan 2031 (Second Revised). Part II: Planning Proposals and Recommendations. Rajkot: Rajkot Urban Development Authority.

Rutherford J and Coutard O (2014) Urban Energy Transitions: Places, Processes and Politics of Socio-Technical Change. Sage Publications Sage UK: London, England. Available at: 
http://journals.sagepub.com/doi/abs/10.1177/0042098013500090 (accessed 8 March 2017).

Rutland T and Aylett A (2008) The Work of Policy: Actor Networks, Governmentality, and Local Action on Climate Change in Portland, Oregon. Environment and Planning D: Society and Space 26(4): 627-646. DOI: 10.1068/d6907.

Ryan D (2015) From commitment to action: a literature review on climate policy implementation at city level. Climatic Change 131(4): 519-529. DOI: 10.1007/s10584-015-1402-6.

Sallis JF, Spoon C, Cavill N, et al. (2015) Co-benefits of designing communities for active living: an exploration of literature. International Journal of Behavioral Nutrition and Physical Activity 12(1): 30. DOI: 10.1186/s12966-015-0188-2.

Scott J (1999) Seeing Like a State: How Certain Schemes to Improve the Human Condition Have Failed. Revised ed. edition. New Haven, Conn.: Yale University Press.

Selvam N (2019) Corporation's eviction drive along waterbodies gains momentum | Coimbatore News - Times of India. Available at:

https://timesofindia.indiatimes.com/city/coimbatore/corpns-eviction-drive-alongwaterbodies-gains-momentum/articleshow/69919651.cms (accessed 28 October 2019).

Seto KC, Davis SJ, Stokes EC, et al. (2016) Carbon Lock-In: Types, Causes, and Policy Implications. Annual Review of Environment and Resources 41(1): 425-452. DOI: 10.1146/annurev-environ-110615-085934.

Silver J (2017) The climate crisis, carbon capital and urbanisation: An urban political ecology of low-carbon restructuring in Mbale. Environment and Planning A: Economy and Space 49(7): 1477-1499. DOI: 10.1177/0308518X17700393.

Sivaramakrishnan KC (2013) Revisiting the 74th Constitutional Amendment for Better Metropolitan Governance. Economic and Political Weekly 48(13): 86-94.

Skymet (2017) Rajkot receives $95 \mathrm{~mm}$ of heavy rains, flood threat continues. Available at: https://www.skymetweather.com/content/weather-news-and-analysis/with-348-mm-rainsrajkot-breaks-a-decade-old-record-flooding-likely/ (accessed 28 October 2019).

Slocum R (2004) Polar Bears and Energy-Efficient Lightbulbs: Strategies to Bring Climate Change Home. Environment and Planning D: Society and Space 22(3): 413-438. DOI: $10.1068 /$ d378.

Solecki W, Rosenzweig C, Dhakal S, et al. (2018) City transformations in a $1.5^{\circ} \mathrm{C}$ warmer world. Nature Climate Change 8(3): 177-181. DOI: 10.1038/s41558-018-0101-5.

Sundaram R (2010) Pirate Modernity: Delhi's Media Urbanism. Routledge.

The Hindu (2018) Book Velumani and his benamis for graft, says DMK. The Hindu, 11 September. Chennai. Available at: https://www.thehindu.com/news/national/tamilnadu/book-velumani-and-his-benamis-for-graft-says-dmk/article24920305.ece (accessed 28 October 2019). 
The Indian Express (2019) Rajkot Municipal Corporation to raze solid waste plant of blacklisted firm. In: The Indian Express. Available at:

https://indianexpress.com/article/cities/ahmedabad/rajkot-municipal-corporation-to-razesolid-waste-plant-of-blacklisted-firm-5821489/ (accessed 28 October 2019).

The New Indian Express (2018) DMK moves court against min SP Velumani-. Available at: http://www.newindianexpress.com/states/tamil-nadu/2018/oct/02/dmk-moves-courtagainst-minister-s-p-velumani-1879927.html (accessed 28 October 2019).

Transparent Chennai (2015) Urban Governance Case Study Coimbatore. Mumbai: Centre for Urban Policy and Governance, School of Habitat Studies, Tata Institute of Social Sciences,.

van der Heijden J, Patterson J, Juhola S, et al. (2019) Special section: advancing the role of cities in climate governance - promise, limits, politics. Journal of Environmental Planning and Management 62(3): 365-373. DOI: 10.1080/09640568.2018.1513832.

von Stechow C, McCollum D, Riahi K, et al. (2015) Integrating Global Climate Change Mitigation Goals with Other Sustainability Objectives: A Synthesis. Annual Review of Environment and Resources 40(1): 363-394. DOI: 10.1146/annurev-environ-021113095626.

Wachsmuth D (2014) City as Ideology: Reconciling the Explosion of the City Form with the Tenacity of the City Concept. Environment and Planning D: Society and Space 32(1): 75-90. DOI: 10.1068/d21911.

Weber M (1921) Economy and Society. 2013 Edition, Two Volume Set. Roth G and Wittich C (eds). Berkeley: University of California Press.

Weiss RS (1995) Learning From Strangers: The Art and Method of Qualitative Interview Studies. 1 edition. New York: Free Press.

While A and Whitehead M (2013) Cities, urbanisation and climate change. Urban Studies 50(7): 1325-1331.

WWF-India (2018) Smart City of Rajkot declared the National Winner of WWF's One Planet City Challenge 2018. Available at: https://www.wwfindia.org/?17681/Smart-City-of-Rajkotdeclared-the-National-Winner-of-WWFs-One-Planet-City-Challenge-2018 (accessed 6 December 2019).

Zérah M-H (2009) Participatory governance in urban management and the shifting geometry of power in Mumbai. Development and Change 40(5): 853-877. 